Makale Geliș | Received: 12.02.2021

Makale Kabul | Accepted: 27.02.2021

DOI: $10.18795 /$ gumusmaviatlas. 879432

Mavi Atlas, 9(1)2021: 295-315

Araştırma Makalesi | Research Article

\author{
Salman NARLI \\ Doktora Öğrencisi|PhD Student \\ Fatih Sultan Mehmet Vakıf Üniversitesi, Lisansüstü Eğitim Enstitüsü, İstanbul-TÜRKIYYE \\ Fatih Sultan Mehmet Vakıf University, Institute of Graduate Studies, Istanbul-TURKEY \\ ORCID: 0000-0001-8406-1334 \\ salman_narli@hotmail.com
}

\title{
Necip Fazıl Kısakürek'in Hatırat Kitaplarında Sosyal ve Siyasi Muhteva
}

Öz

Edebî türler içinde otobiyografik içeriğe dayanan eserlerin başında hatırat metinleri gelmektedir. Hatırat kitapları, şair ve yazarların kaleminden çıktığında üç alanda kaynaklık özelliğine sahiptir. Bu eserler, ilk olarak yazarının özel hayatına 1ş1k tutar. İkinci olarak edebiyat hayatına kaynaklık edebilir. Üçüncü alanda ise anlatılan yılların toplumsal, kültürel ve siyasi durumunu gösterir. Toplum davalarını mesele edinmiş şair ve yazarların hatıratında bilhassa üçüncü alan dikkat çeker. Necip Fazıl Kısakürek’in hatırat kitapları böyle eserlerdir. 1904-1983 yılları arasında yaşayan Kısakürek, Osmanlı İmparatorluğu'nun son yıllarını ve Türkiye Cumhuriyeti'nin birçok kritik dönemini idrak etmiş bir mütefekkir ve edebiyatçıdır. Eserleriyle başarılı bir sanatkâr olarak kendini edebiyat tarihine kabul ettirirken hayatı ve fikirleriyle nesillerin dünya görüşü üzerinde istikamet verici bir isim olmuştur. Necip Fazıl Kısakürek, şair ve yazar olarak çok sayıda eser kaleme almış velût bir isimdir. Eserlerinden bir kısmı hatırat türü metinlerdir. Yazar, bu türdeki kitaplarında çocukluktan itibaren hayatını ve geçirdiği aşamaları anlatır. Bununla birlikte Türkiye'nin gidişatıyla ilgili birçok konuya değinmiştir. Makalede yazarın bahsettiği sosyal ve siyasi konular incelenecek, bunlar hakkında Necip Fazıl’ın görüssleri verilecektir. Yazarın tek parti yıllarından itibaren gündemde kaldığ1 görülmektedir. Bazen edebî yönüyle ama genellikle fikirleri ve aksiyoner kimliğiyle Necip Fazıl Kısakürek toplumsal ve siyasal hayatın içinde yer almıştır. İktidarlarla ilişkisi, siyasetçiler, ülkenin fikir hayatı, basın dünyası ve dinî-fikrî aksiyonu anılarında görülen başlıca sosyal ve siyasi konulardır.

Anahtar Kelimeler: Necip Fazıl Kısakürek, edebiyat ve toplum, hatırat, Tek Parti Dönemi, Demokrat Parti.

\section{Social and Political Contents in Necip Faz1l Kısakürek's Memoir Books}

\begin{abstract}
Among the literary genres, memoirs are the leading works based on autobiographical content. When memoir books are written by poets and writers, they have the feature of being a source in three areas. These works first shed light on the writer's private life. Secondly, it can be a source of literary life. The third area shows the social, cultural and political situation of the years described. Particularly, the third area is striking in the memoirs of poets and writers who have taken social causes as a matter. Necip Fazıl Kısakürek's memoirs are such works. Necip Fazıl Kısakürek, who lived between the years 1904-1983, is a thinker and writer experienced the last years of the Ottoman Empire and the most critical periods of the Republic of Turkey. While establishing himself as a successful artist in the history of literature with his works, he has become an important figure with his life and ideas for the generations' worldview. Necip Faz1l Kisakürek is a prolific figure who has produced many works as a poet and writer. Some of his works are memoirs. In his memoirs, the author tells about the life stages he has gone through since childhood. He also touches on many issues related to the course of the country. In this article, the social and political issues mentioned by the author will be examined, and Necip Fazil's views will be revealed. The author seems to have been active since the one-party years. Necip Fazıl Kısakürek took an active part in the social and political life, sometimes with his literary works but generally with his views and statements. His relationship with the government, politicians, the country's intellectual life, the press and its religious-intellectual action are the main social and political issues seen in his memoirs.
\end{abstract}

Keywords: Necip Fazıl Kisakürek, literature and society, memoir, Single-Party Era, Democratic Party. 


\section{Giriş}

Modern Türk edebiyatında birçok şair ve yazar aynı zamanda fikir adamı yönüyle karşımıza çıkmaktadır. Tanzimat'tan sonra edebiyatçılar fikirlerini açıklamaya, tarih, toplum, devlet idaresi ve ülkenin geleceği gibi konularda görüşlerini bildirmeye başlamışır. Namık Kemal'den itibaren çok sayıda isim, burada sayılan alanlar üzerinde gazete ve dergilerde yazılar kaleme almış, ayrıca eserler vermiştir. Cumhuriyet yılları, edebiyatın toplumsallaşması yönündeki bu eğilimin artarak devam ettiği bir dönemdir.

Cumhuriyet Dönemi Edebiyatı'nda sosyal ve siyasi konular, belli dönemlerde ciddi gerilimlere sebep olmuştur. Bazı edebiyatçılar, belirli görüşlerin ve ideolojilerin taşıyıcısı şahsiyetler haline gelmiştir. Necip Fazıl Kısakürek bu isimlerden biridir. Onun kitapları muhafazakâr kitleler tarafindan birer başyapıt sayılmış, Necip Fazıl'a sanatkâr yönü yanında ve belki bunun üstünde bir dava adamı kimliği verilmiştir. Dönemi içinde cesur bir düşünce atılımı yaparak resmi kültürelideolojik söylemin karşısında tavır alabilmiştir. 'Batı'nın bir ideal olarak görüldügü, Doğu'nun ise köhne bir geçmiş olarak telakki edildiği bir devirde ortaya koyduğu Doğu ve Bat1 telakkisi, bu bağlamda yepyeni bir perspektifin oluşmasına kapı aralamıştır.” (Koçak, 2020: 110).

Farklı türlerde ve çok sayıda eser vermesi, dergiler çıkarması, konferansları ve bunların hepsine sinmiş polemikçi tavrıyla Necip Fazıl Kısakürek Cumhuriyet Dönemi Edebiyatı içinde önemli bir yerde durmaktadır. Onun yoğun fikir ve edebiyat mesaisi, bir aksiyon hâline gelmiş, şairin yazıp söyledikleri yanında yaşadıklarını da dikkat çekici hâle getirmiştir. Necip Fazıl Kısakürek'in kendi hayatına dair kaleme aldığı eserler onun aksiyonunu ve fikirlerini anlama bakımından ciddi kaynaklardır. Hatırat türü eserlerinde çocukluğundan itibaren hayatının detayları okunmaktadır. Ancak eserler, şairin hayatındaki farklı zamanlara ve konulara odaklanarak yazılmıştır. Cinnet Mustatili (ilk basım tarihi 1953) kitab1, hapishane günlerini kaleme aldığ1 eseridir. Hac'dan Çizgiler, Renkler ve Sesler ve Nur Mabyalar (ilk basım tarihi 1973) hac ibadeti için yaptığ1 yolculuğu anlattığ1 eseridir. O ve Ben (ilk basım tarihi 1974) kitabı, şairin tasavvufî bir yola girmeden önceki ve sonraki hayatını yansıtır. Bâbrâli (ilk basım tarihi 1975) kitabı ise edebiyat ve basın hayatı içindeki anılarına ağırlık verdiği eseridir. Kafa Kâğıdı, otobiyografik izler taşımakla birlikte bir roman olarak değerlendirilmektedir. Bu nedenle makalede incelenecek eserlerden değildir. Hac'dan Ci zigiler, Renkler ve Sesler ve Nur Mabyalar kitabının içeriğinde sosyal ve siyasi konular olmadığı için bu kitap da makalede incelenmemiştir.

Necip Fazıl Kısakürek, yukarıda sayılan hatırat türü kitaplarda kişisel hayatının yanında, içinde bulunduğu sosyal ve siyasi şartları, bunlar hakkındaki görüşlerini dile getirir. Yirminci yüzyılın başlarından 1980'lere kadar uzanan hayatı boyunca büyük olayların tanığı olmuştur. Yazar tanıklığını tarafsız bir gözle değil, genellikle sübjektif değerlendirmelerle eserlerine yansıtmıştır. Bu bakımdan onun hatırat kitaplarında sosyal ve siyasi konulara bakışı, dünya görüşünün neticesi olan değerlendirmelerdir. Anılarını kaleme almasındaki amacı, diğer birçok eserinde de görüldüğü gibi topluma karşı duyduğu sorumluluktur. Özel hayatını anlatmak veya toplum içindeki konumunu göstermek için yazmamıştır. Ya da yazma kabiliyetini göstermek gibi bir amacı yoktur. "Amac1 kendinden ibaret bir yazma eylemini anlamlı bulmayan Necip Fazıl, diğer eserlerinde olduğu gibi hatıralarını yazma sürecinde de "Şahıs üstü bir gayeye hizmet etmek kaygısı"na bağlı kalmıştır." (Kahraman, 2010: 298).

Kitaplarında bahsettiği sosyal ve siyasi muhtevayı, Türkiye'nin geçirdiği aşamaları dikkate alarak üç dönemde incelemek gerektiği kanaatindeyiz: Cumhuriyetin ilanına kadar sosyal ve siyasi muhteva, 1923-1950 aras1 sosyal ve siyasi muhteva, 1950 sonrasi sosyal ve siyasi muhteva. Yirminci yüzyıl başlarından 1970’lere kadar uzanan yıllar, yazarın dikkati ve tanıklı̆̆ının sınırları içinde değerlendirilecektir. 


\section{Cumhuriyetin İlanına Kadar Sosyal ve Siyasi Muhteva}

1904 y1lında dünyaya gelen Necip Fazıl Kısakürek çocukluk ve ilk gençliğini, Osmanlı İmparatorluğu'nun son yıllarında yaşar. Şair; II. Meşrutiyet’in ilanı, İttihat ve Terakkinin iktidar yılları, Trablusgarp Savaşı, Balkan Savaşları, I. Dünya Savaş1 ve Millî Mücadele yıllarında büyür. Ancak bu yıllarda ülkenin yaşadığ mühim hadiseleri hatırat kitaplarında işlememiştir. 1910’lu yılların sosyal ve siyasi atmosferini vermemiş, çocukluk ve ilk gençlik anılarında kişisel hikâyesini anlatmayı tercih etmiştir. Bu durum normal karşılanmalıdır çünkü henüz yaşça çok küçük olduğu dönemde ülkedeki sosyal ve siyasi ortamı idrak etmesi ve yıllar sonra hatıratına alması beklenemez. Dönemle ilgili yazdıkları içinde daha çok ev ve ailesi, okuduğu romanlar ve kaydedildiği okullar dikkat çeker. Bu yıllarla ilgili hatırladıklarını $O$ ve Ben kitabının başlarında görürüz. Cumhuriyete kadar olan sürede henüz edebiyat hayatında şöhrete kavuşmamıştır.

$O$ ve Ben kitabının Necip Fazıl'ın çocukluğundan bahseden sayfalarında şairin kişisel hayatıyla ilgili olan ama Batıllış̧ma olgusunun simgesel unsurlarının geçtiği detaylara rastlanır. Bunlardan biri yabancı mürebbiye, diğeri yabanc1 okullarıdır. Varlıklı bir dedenin torunu olan ve konakta büyüyen Necip Fazıl, babasının Fransızca öğretmeni ve kendisinin mürebbiyesi olan bir kişiden bahseder. Kendisinden matmazel olarak bahsedilen bu mürebbiye altmış yaşlarında ve bekârdır (Kısakürek, 1998: 11-12). Devrin eğitim anlayışı icabı evin içindeki yabancı mürebbiye uygulamasının XX. yüzyılın başlarında devam ettiği görülmektedir. Batılılaşma olgusuyla birlikte görülmeye başlanan diğer unsur yabancıların kurduğu okullardır. Necip Fazıl, çok kısa süren Mahalle Mektebi devresinden sonra Gedikpaşa'daki Fransız Mektebine kaydedilir. Buradaki öğrenciliği kısa sürer ve sonra aynı semtteki Amerikan Kolejine verilir. Henüz 10 yaşında bile değildir. Oradan da sıkılır ve daha sonra birçok okul değiştirecektir (Kısakürek, 1998: 29-30). Evdeki mürebbiyeyle birlikte tercih edilen bu okullar birlikte düşünüldügünde o yıllarda varlıklı aileler arasında Avrupaî terbiyenin muteber kabul edildiği anlaşılmaktadır.

Necip Fazıl, 18 yaşındayken mühim bir olaya şahitlik eder. Millî Mücadele zaferle sonuçlanmıs, 11 Ekim 1922'de Mudanya Mütarekesi ile savaş resmen sona ermiştir. Harbin komutanlarından Refet Paşa antlaşmadan sonra 19 Ekim 1922'de İstanbul'a gelir. Necip Fazıl, Millî Mücadele'nin kazanılmasının ve Refet Paşa'nın İstanbul'a girişinin halkta büyük bir coşku uyandırdığını nakleder, bütün İstanbul'un, Paşa'nın geçeceği yollarda bulunduğunu yazar (Kısakürek, 1998: 54). İstanbul'da bir müddet kalan Paşa, çeşitli temasları içinde Dârülfünûna da gelerek bir konuşma yapmıştır. Necip Fazıl, o yıllarda üniversitede öğrencidir. "Refet Paşa elinde bir Alman mecmuası bağırıp duruyor: Bakın şu mecmua ne yazıyor? Zaferin peşinden, Anadolu Hükümeti, kısa zamanda Cumhuriyeti ilân edecekmiş!.. Bu gidişin varacağı nokta burasıymış. Asla, asla efendiler, millî hükümet ve Türkiye Büyük Millet Meclisinin asla böyle bir niyeti yoktur!..” (Kısakürek, 1998: 55). Refet Paşa'nın bu açıklamaları, Millî Mücadele'yi yürüten kurmay kadro içinde cumhuriyet fikrinin henüz herkesçe kabul görmediğini gösterir. Ancak bir yll sonra, asla diyerek karşı çıktığ1 rejim kurulduğunda Paşa'nın sözlerinin geçersiz kaldığı anlaşılacaktır. Burada önemli bir hususu belirtmek gerekir; Refet Paşa'nın cumhuriyet rejimine karşı olması, onu saltanat yanlısı olarak düşündürmemelidir. “(...) Refet Paşa'nın konuşmalarında saltanat kadar Cumhuriyet idaresine de muhalif olduğu gözlenmektedir ki, bundan da saltanatın kaldırılacağını bilmekle beraber, yeni idarenin cumhuriyet olacağını bilmediği anlaşılmaktadır." (Kaya, 2008: 113). Ayrıca onun konuşmalarında meşrutiyeti de tasvip etmediği ve meşrutiyet ile cumhuriyet arasında bir fark görmediği ortaya çıkar. $\mathrm{O}$, Ankara'daki idare şeklini bu iki kavramdan bağımsız bir millet egemenliği olarak düşünmektedir. İstanbul'daki temaslarında buna değinmiştir; Dârülfünûnda ve Şehremanetinde aynı tarihte konuşmalar yapar.

21 Ekim'de Darülfünûn'da yapmış olduğu konuşmasında, "Saltanat-1 milliyenin tesisinden sonra zafer ve istiklâl kazanıldı." diyor ve yabancıların Anadolu Hükümeti'nde bir "cumhuriyet fikrı” aradıklarını anladığını söylüyordu. Aynı konuşmada, meşrutiyetle 
cumhuriyet arasındaki fark1 "Birisinin başında hanedan takip eden bir zat, diğerinin bașında hanedan takip etmeyen bir zat vardır." şeklinde izah ediyordu. (...) Cumhuriyet yönetimi hakkındaki düşünceleri de "köhne bir fikir" olarak değerlendirdikten sonra, şunları söylemekteydi: "Bu fikirler bizden çok uzaktır. Zaten ben esas itibariyle cumhuriyeti memleketimizin bünyesi için daha zararlı görürüm... Bizim bulduğumuz usul başka. Bilâkis bu milletin bünyesine uygun vaziyettir. Bu milletin başına bu kadar belâdan sonra bir de cumhurreisi intihabı beliyyesini sokmaya ne lüzum var. Biz milletin hükümetini istiyoruz... Millî hakimiyetten ve millî saltanattan maksat budur." (Vakit 23 Teşrinievvel 1338'den aktaran: Akbulut, 2006: 24-25).

Cumhuriyetin millet egemenliğini sağlamayacağı görüşü, o yıllarda bu kavramın Türk siyasi kültüründe farklı algılandığını gösteriyor. Ayrıca Refet Paşa, cumhuriyeti savunanların millî egemenliğin tesisi dışında hedefleri olduğunu düşünmüş olabilir. Millî Mücadele'nin zaferle sonuçlandığ1 tarih ile cumhuriyetin ilanı arasındaki sürede ülkede bir rejim meselesinin ve tartışmasının olduğu, bunun Millî Mücadele’yi yürüten kurmay kadro arasında yaşandığı açıktır. Necip Fazıl'ın hatıratında şahit olduğu konuşmanın arka planında bu gerilim vardır. Ona göre cumhuriyet, bir millet egemenliği sağlamamaktadır.

Necip Fazıl, Refet Paşa'nın Dârülfünûndaki konuşması hakkında detaylı yorumlar yapmaz, dönemin siyasi eğilimi hakkında değerlendirmede bulunmaz ancak daha sonra Refet Paşa'nın gözden düştüğ̈üü (Kısakürek, 1998: 55) yazar. Gözden düşmesinin sebebi cumhuriyetin ilanına ve sonrasında gerçekleştirilen siyasi icraatlara mesafeli duruşu olmalıdır. Birçok önde gelen isim gibi o da Millî Mücadele yıllarındaki söylem ile sonrasında oluşacak rejim arasındaki çelişkiler sebebiyle cumhuriyetten sonra etkisini yitirmiştir. Millî Mücadele'yi yürüten askeri kadro arasındaki görüş farklılı̆̆1, cumhuriyetin ilanından sonra somutlaşmış ve Millî Mücadele'de mühim görevler almış birçok komutan cumhuriyetin ilk yıllarıyla birlikte tasfiye olmuştur. Kâzım Karabekir, Cafer Tayyar, Ali Fuat Cebesoy, Hüseyin Rauf Orbay ve Refet Bele gibi isimler cumhuriyetin ilk yllarında Terakkiperver Cumhuriyet Firkasında yer almış ve parti Şeyh Sait İsyanı'ndan sonra kapatılmıştır. Bu durum onların tasfiyesinde belirgin bir sebep olmuştur. Ayrıca adı geçen kumandanların ortak bir özelliği orta sınıfların geleneksel tarihe bağlı kültürünü, kimliğini ve cemaat ruhunu paylaşan (Karpat, 2019: 184) insanlar olmalarıdır. Bu özelliklere sahip insanlarla, radikal şekilde modernleşme ve Batıllılaşma yanlısı yeni rejim idarecilerinin bazı noktalarda çatışmaları kaçınılmaz olmuştur. İsmet İnönü'nün cumhurbaşkanı olmasının ardından, tasfiye olan bazı isimler yeniden siyasette yerlerini alacaklar ama etkili ve belirleyici bir konum elde edemeyeceklerdir.

\section{3-1950 Aras1 Sosyal ve Siyasi Muhteva}

Cumhuriyetin ilanı, Millî Mücadele sonrasında ortaya çıkan sınırlar üzerinde yeni bir devletin kuruluşudur. Türkiye Cumhuriyeti, Osmanl İmparatorluğu'nun modernleşme hamlelerinden kurumlar ve etkiler tevarüs ederek yeni bir rejim halinde tarih sahnesine çıkar. Ancak cumhuriyetin modernleşme hamleleri ilk yllardan itibaren radikal değişiklikler şeklinde seyretmiş; hukuk, eğitim, kültür, sosyal hayat ve idarede devrimler gerçekleşmiştir. Edebiyat hayatı ve basın yayın faaliyetleri bu radikal değişimden etkilenmiştir. Kitaplar, dergiler ve gazeteler yirmili ve otuzlu yıllar boyunca büyük oranda rejim lehinde, inkılâpları öven ve sahiplenen, devletin görmek istediği makbul organlar şeklindedir. Edebiyatçlara verilen resmi ve gayriresmî görevler, kimi edebiyatçılarınsa bir görev almaksızın kendi isteğiyle yazdığı eserler edebiyatta bir inkılap kanonu oluşmasına neden olmuştur. Bu konuda Selçuk Çıkla, cumhuriyetin ilk yıllarında bazı kişi ve kurumların bir inkılâp edebiyatı kanonu oluşturma doğrultusunda çalısma yaptıklarını belirtir. Bunlar rejime bağlı yazar ve şairler, dönemin bazı siyasîleri, çeşitli yayın organlarının yöneticileri ile parti, hükümet, Halkevleri, Basın Genel Müdürlüğü gibi kurumlardır (Çıkla, 2007: 53). Ülkede devlet eliyle yapılan hukuki ve idari değissimlerin yanında kültürel ve zihinsel bir devrim gerçekleştirmek hedeflenmektedir. Yirmi yedi yıllık Tek Parti Dönemi'nde Atatürk ve İnönü 
cumhurbaşkanlığ1 yapmıştır. Dönem bu isimler üzerinden iki kısım halinde incelenir. Ancak İnönü'nün cumhurbaşkanlığı yılları, İkinci Dünya Savaşı'na denk geldiği için bu da kendi içinde iki dönemdir. 1938 ile 1945 aras1 y1llar ve 1945’ten 1950'ye kadar geçen y1llar. İnönü döneminde, Atatürk dönemine göre bazı değişimlerin hissedildiği, bazı olgularınsa devam ettiği görülür.

İnönü devri, toplumun aşı1r ideolojik bir ortamdan daha 1lımlı, doğal ve topluma daha yakın bir hayat şekline geçişini ifade eder. Ancak İnönü’nün bu 1lımlllı̆̆ yanında laiklik ve kültür politikasında aşırı bazı hareketlerine de rastlanır. İnönü devrinin 1945'e kadar olan ilk kısmı İkinci Dünya Savaşı'nın sebep olduğu bunalımlardan etkilenmiş, ikinci kısım yani 1950’ye kadar olan süre ise çok partili demokrasiye geçiş mücadelesi içinde çalkalanmıştır. (Karpat, 2019: 162)

Necip Fazıl'ın tek parti yıllarıyla ilgili genel kanaati olumsuzdur. O, 27 yıllık dönemi, maneviyattan uzaklaşma ve işgalden kurtarılan ülkenin daha sonra başka belalara dûçâr edilmesi şeklinde değerlendirir. Rejimin Batılı değerleri referans alan uygulamalarına karşı çıar.

Kısakürek, Cumhuriyet dönemi modernleşmesini Tanzimat'ın bir devamı ama en sıkıntılı dönemi olarak görür. Ve bu çerçevede Mustafa Kemal Atatürk'e dolaylı, hatta müstear isimlerle yazdığı yerlerde direkt eleştiriler vardır. Genel olarak Kısakürek'in yazdıkları, CHP ve İnönü üzerinden Kemalist modernleşmeyi mahkûm eden bir literatür oluşturmaktadır. Kemalist modernleşmeyi “Türk'ün ruh kökünden, maneviyatından, mukaddesatından” bir uzaklaşma olarak görür. (Duran, 2015: 526)

Yazarın tek parti dönemine dair ilk anıları, henüz üniversite çağındaki yıllara aittir. Genç cumhuriyet, ilk yıllarında yurt dışına öğrenciler gönderme kararı alır. Gönderilenler arasında Necip Fazıl da vardır. Felsefe öğrenimi için Paris'e gider. Devlet bursuyla gittĭgi Paris'te öğrencilikle alâkası olmadan geçen bunalımlı aylar sonunda Türkiye'ye döner. Vapurla geldiği İstanbul'da ülkedeki devrimlerden biri olan şapka ile karşılaşır. Vapur rıhtıma yanaşırken herkesin başında şapka olduğunu fark eder.

Garip şey!.. Herkes şapkalı... O sene Türkiye'de şapka kanununun çıarıldığını biliyordu ama böyle bir manzara göreceğini ummuyordu. Şapkalar başlarda, bir İngiliz’in Hindû kavuğu giymesi gibi duruyor. İçten tepeye çıkma bir şey değil de, tepeden kafaya oturma... Develere de giydirseniz böyle olur. Bir Fransız muharriri "Türkler şapkayı ruhlarına değil, kafalarına geçirdiler!” diye yazmıştı. Ne doğru! Bu muydu Fransa’ya giderken denize fırlattı̆̆ fesin karşıllı̆ı?.. (K1sakürek, 2010: 39-40)

Şairin bu şeklî inkılâbı benimsemediği ve Türk insanına yakıştıramadığı anlaşıllyor. İnsanların şapkayla anormal görüntüsü bir kılık kıyafet detayı olarak kalmayacak, sonraları daha ciddi sorunlara yol açacaktır.

Cumhuriyetin ilanından itibaren yeni rejimin hedeflerine hizmet eden bir edebiyat ve kültür ortamı oluşmaya başlar. Necip Fazıl bu ortamın istisnalarından biridir. Onun ilk dönem eserlerinde sosyal içerikten uzak kalması, eserlerini kullanışlı metinler olmaktan korumuştur diyebiliriz. Adı duyulmaya başladıktan sonra dikkat çeken ve takdir edilen bir şair olmasına rağmen şiirleri, "inkılâpçı” bir içeriğe sahip olmadığı için bağımsız kalabilmiştir. Bununla birlikte edebî yönünün kuvvetli olması ona edebiyatın otorite isimleri arasında otuzlu yillar boyunca ciddi bir sayginlık kazandırmıştır. Necip Fazıl bu saygınlığın neticesi olarak bir millî marş yazması teklifi aldığını nakleder.

Mehmet Akif Ersoy'un kaleme aldığı ve Millî Mücadele yıllarının hatırasını taşıyan "İstiklâl Marşı" 1930'lu yıllarda rejime bağlı kimi isimlerce beğenilmemektedir. Necip Fazıl yeni bir millî marş arandığından söz eder. Ulus gazetesi konuyla ilgili bir müsabaka açar ve konunun ilgilileri bu şiiri ancak Necip Fazıl'ın yazabileceğini düşünmektedir. Konu Necip Fazıl'a iletildiğinde şair, Mehmet Akife ve eserine hürmeti olduğunu ama içinde özel isim geçmemek şartıyla, kendi 
anlayışına göre ve milletten aldığı heyecanı bir marş içinde billurlaştırmak isteğiyle teklifi kabul ettiğini söyler. Bunun üzerine müsabaka durdurulmuş ve Necip Fazıl millî marş olması niyetiyle “Büyük Doğu Marșı”nı kaleme almıştır. Șiir tamamlandıktan sonra Atatürk’ün onayına sunulacaktır ama Atatürk'ün hastalanıp bir süre sonra ölmesiyle millî marș değișikliği projesi iptal edilir. Șiir Necip Fazıl'a kalır, üstelik “Büyük Doğu” kavramı böylece ortaya çıkar (Kısakürek, 1998: 177-178). Bu ifade sonraki yıllarda Necip Fazıl'ın fikriyatını ifade edecek bir anlam kazanacaktır.

Necip Fazıl, yeni bir millî marș aranması konusundan Bâbıâli kitabında da bahseder. Şair burada "İstiklâl Marşı"ndan duyulan rahatsızlığın nedenini açıklar.

Mehmed Âkifin "İstiklâl Marşı" beğenilmiyor ve yerine bir "Millî Marş" yazdırılmak isteniyordu. Hatta Ulus gazetesi bu iş için bir de müsabaka açmıştı. Gaye açıtıt: Âkif in manzumesindeki İslâmî hava, sonu laisizmada karar kılan bir rejimin kaynağındaki heyecana, daha doğrusu maksada uygun sayılmıyordu. Yazana o zamanın parasiyle on bin lira mükâfat verilecek ve şïr Büyük Millet Meclisince kanunla kabûl edilecekti. (Kısakürek, 2010: 242)

Necip Fazıl, kendisine yapıldığını belirttiği teklife cevaben, mevcut rejim havası içinde birtakım şahıs pohpohlamalanı uğruna şiirini alçaltmayacağını belirtir. Özellikle Falih Rıfkı Atay, şairin her şartını kabul edeceklerine dair teminat verir. Necip Fazıl, yazdığı şiirle ilgili olarak Mehmet Akifin eserinde hoşa gitmeyen İslâmî havanın aslında "Büyük Doğu Marşı"nda gizli bir şekilde mevcut olduğunu söyler. "Nur yolu izinden git KILAVUZ'un!” misraindaki kılavuzun herkesin anlayışına göre farklı isimler olabileceğini ama kendisinin bu kelimeyle Hz. Muhammed'i (s.a.v.) kastettiğini açılar (Kısakürek, 2010: 242-243). Necip Fazıl, siyasi bir mesele olarak görülen marş hususunda, bunu değiştirmek isteyenlerle karşıt fikirlerde olmasına rağmen şiirde kendisini o denli kabul ettirmiştir ki marş ona yazdırılmak istenir. Hatıratında konuyla ilgili anlattıklarından bu anlaşllyyor.

Yeni bir millî marş talebiyle ilgili nakledilen bu olay hakkında birbiriyle çelişen bazı bilgiler görüyoruz. Ulus gazetesi, Necip Fazıl'ın da sözünü ettiği gibi bir müsabaka açmıştır ancak bu müsabaka gazetede bir millî marş yazımı müsabakası olarak ilan edilmez. 10 Kasım 1937 tarihli Ulus'ta "Pek yakında Türkiye Cumhuriyeti'nin 15. yıl dönümü için gazetemiz bir marş müsabakası açıyor. Güfte için 500 lira, beste için 1000 lira mükâfat vereceğiz." (Ulus, 10.11.1937: 1) denmektedir. 14 Kasım tarihli gazetede aynı müsabakadan tekrar bahsedilir, "Marş Müsabakamız" başlığıyla verilen ilanda müsabakaya katılacak güfte yazarlarının uyması gereken şartlar açıklanır (Ulus, 14.11.1937: 6). 11 Ocak 1938 tarihli gazetede ise "Marş Müsabakamız" başlıklı ilanın altında bu kez beste yapacak adaylar için uyulması gerekli bazı kurallardan söz edilir. İlanda şiirin adı “15’inci Yıl Marşı” olarak yazılır (Ulus, 11.01.1938: 4). Ulus'taki ilanlarda “İstiklâl Marşı” yerine geçecek bir şiirden söz edilmez. Cumhuriyetin 15. yllı için "15. Yıl Marşı”" adlı bir şiir yarışması söz konusudur. Bu bilgilerle Necip Fazıl'ın bir milli marş müsabakasından söz ettiği pasajlar çelişmektedir. Ancak Necip Fazıl'ın şiiri yarışmadan sonraki yıl, 29 Mart 1939 tarihinde, Yedigün mecmuasında "Türk Millî Marşı" başlığıyla yayımlanır. Şïr daha sonra bazı değişikliklerle Büyük Doğı'da “Büyük Doğu Marşı” olarak tekrar yayımlanacaktır (Karaca, 2016). Yedigün'de çıkan şiirin adı, Necip Fazıl'ın hatıratını desteklerken Ulus'un ilanlarındaki ifadeler bir milli marş müsabakasının söz konusu olmadığını göstermektedir. Ulus'un açtığı yarışmanın resmî bir millî marş belirleme yarışması olmadığ1 görülüyor. Necip Fazıl'ın şiirinin Yedigün'de “Türk Millî Marşı” başlığıyla geçmesi, şiirin muhtevasından dolayı verilmiş yakıştırma bir isim olmalıdır.

1930’ların sonundan 1945’e kadar geçen y1llarda ülkedeki en önemli gündemlerden biri II. Dünya Savaşı'dır. Necip Fazıl hatırat kitaplarında bu olayla ilgili bazı değerlendirmeler yapar. Türkiye'nin savaşa girip girmeyeceği herkesin merak ettiği sorudur. Ülke, kendisiyle ilgisi olmayan bir savaşta taraf olmaya zorlanırsa ne yapacaktır, hangi tarafta yer alması gerekir, savaşa girme durumunda netice ne olabilir soruları halk arasında ve basında konuşulmaktadır. Necip Fazıl, 1941 
yılında Almanların sınırlarımızda olduğu zamanda bir gazetede çıkan yazılarında Türkiye'nin savaşa girmesinin an meselesi olduğunu yazar (Kisakürek, 1998: 201). Bu konuda yanılan yazar, savaştaki taraflarla ilgili basın dünyasının tavrını nakleder. II. Dünya Savaşı'nda belli başlı üç ideolojinin varlığı söz konusudur: Almanya ve İtalya'nın temsil ettiği nazizm-faşizm, Batı Avrupa ve ABD'nin temsil ettiği demokrasiler ve Sovyetler Birliği’nin temsil ettiği sosyalizm. Necip Fazıl, bunların hepsinin basın hayatında destekçileri olduğunu belirtir.

İkinci Dünya Savaşı'nın ilk yıllarında Bâbıâli üç kampa bölümlü... Kendi tabirlerince "hak ve hürriyet cephesi" demokrasileri tutanlar, Nazilere yapışmaya kalkanlar ve Sovyetlere ümit bağlayanlar... Mistik șair, bu üç grubu, hava-civacilar, muhteris köleler ve dirilișsiz ölüm davetçileri diye vasıflandırıyor; bunlardan her birinin rakibinde keşfettiği marazın tek devasını İslâmiyet'te buluyor ve buna rağmen İslâm'ın zaferi noktasından, Batı âleminde faydalanılacak zaaf plânını elden kaçırmamak için biricik politikayı demokrasilere destek olmakta görüyor ve ona göre, çalakalem, yazıyor, yazıyor. (...) İngiliz, Alman ve Moskof sefaretlerinin kasaları boyuna işliyor ve Bâbıâli, deliğine para atıldıkça işleyen şarkı makinelerine denk, bunlara ait marşları habire çalıp duruyor. (Kisakürek, 2010: 248-249)

Savaș boyunca Bâb-1 Âli'nin tavrını ve Necip Fazıl'ın savaştaki taraflara bakışını gösteren bu değerlendirmeler II. Dünya Savaşı yıllarında basının halini özetler mahiyettedir. II. Dünya Savaşı döneminde gazetelerin yayın politikalarıyla ilgili yapılan tespitlere göre Ulus gazetesi hükümet yanlısıdır. Akşam, Vatan, Yeni Sabah, Tanin, Son Telgraf, Vakit ve Tan gazeteleri müttefik devletler tarafını desteklemiştir. Bunlar içinde Tan gazetesi özellikle Sovyetler Birliği lehinde yayın yapmıştır. Cumburiyet ve Tasvir-i Efkâr ise mihver devletlerini desteklemiştir (Yavuz, 2016: 9). Necip Fazıl'ın değerlendirmesi burada bahsi geçen yayın organlarının tavrını büyük ölçüde açıklamaktadır. Buna göre Nazileri destekleyenler mihver devletleri yanlısıdır; Sovyetler Birliği’ni destekleyen yayın organı Tan gazetesidir; batılı demokrasileri destekleyenler ise Sovyetler dışındaki müttefik devletlerin yanlısı gazetelerdir. Necip Fazıl'ın, benimsemese de, demokrasiler dediği kapitalist devletler tarafinı desteklemesi pragmatik bir yaklaşımdır. 1945'te Nazilerin kaybetmesiyle uluslararası siyasette iki ana eğilim oluşacak ve bu şekilde Soğuk Savaş yılları başlayacaktır. Necip Fazıl'ın savaş devam ederken demokrasiler tarafını bir taktik olarak destekler görünmesi, Soğuk Savaş yıllarında Batılı demokrasileri desteklemek şeklinde devam etmeyecek ama Sovyetler Birliği düşmanluğına dönüşecektir. Türkiye'deki sağ hareketlerin ortak düşmanı Sovyetler Birliği’ne yönelik kinin oluşmasında Türk sağını etkileyen en önemli isimlerden Necip Fazıl'ın katkıları büyüktür. Burada şunu da belirtmek gerekir ki II. Dünya Savaşı'na girmiş devletlerin temsil ettiği ideolojilerin hiçbiri Necip Fazıl'ın dünya görüşüyle uyumlu değildir. Buna rağmen yazarın, politika icabı demokrasiler tarafını tutmasının ne anlama geldiğini detaylıca açılamadığı görülür. Batı demokrasilerinin temsilcisi devletlerin savaştaki galibiyetinin nasıl faydaları olacağı, Necip Fazıl'ın yazılarında etraflıca işlenmez; yazar bu bakımdan eleştirilmiştir.

Ne yazık ki Necip Fazıl bu satırları ile açık bir tercih ortaya koymakla beraber; bu tercihin gerekçeleri, yaslandığı doneler hakkında hemen hiçbir yorumda bulunmuyor. Yani demokrasi ülkelerini savaşta desteklemekle, İslam adına hangi pratik ve pragmatik sonuçlar hasıl edecekti? Babıâli'de yer bulmayan bu tür gerekçelere, savaşa ilişkin yazılarında da rastlamak mümkün olmuyor. (Türinay, 1994: 148)

Türk basınını ve kamuoyunu 1940'lı yıllarda yakından ilgilendiren konulardan biri de Tan gazetesine yapılan baskındır. Bu gazete II. Dünya Savaşı yıllarında ve sonrasında oluşan siyasi vaziyet içinde Sovyetler Birliği’ne yakın duran ve bu yönüyle farklı kesimlerin hedefi haline gelen bir kuruluştur. Gazete 4 Aralık 1945’te baskına uğramış, matbaası kullanılamayacak hale getirilmiştir. Üniversite gençliğinin komünizm karşıtı hassasiyeti üzerine gerçekleşen olaydan sonra gazete faaliyetine son vermek zorunda kalır. Tan'ın o zamanki sahibi ve yazarı Zekeriya Sertel ve 
gazetede yazarlık yapan eşi Sabiha Sertel, öfkenin hedefindeki kişilerdir. Saldırı yapıldıktan sonra basın, baskını yapan gençlere sahip çıkan ve olaydan memnuniyet duyan bir tavır ortaya koymuştur.

Dönemin basını ve önde gelen yazarları için Tan gazetesi ve Serteller, Moskova ile iş birliği içindeki 'Kızıllar' ve 'vatan hainleri'dir. Bu nedenle, 4 Aralık 1945 günü Tan gazetesinin yayın hayatına son veren saldırıya herhangi bir tepki göstermeyen basın, olayı, "Gençliğin haklı tezahürü" olarak vermiştir. Basın, milli duygulara saldıran Tan'a gereken cevabı veren gençliğin, 'vakarlı', 'heyecanlı' bulduğu bu eyleminden duyduğu 'memnuniyeti' ve 'gururu' açıkça dile getirmiş̧ir. (Acar, 2012: 9)

Necip Fazıl Kısakürek'in bu olaya bakışı, gazetenin böyle bir saldırıyı hak ettiği şeklindedir. Nitekim Tan gazetesi ona göre de son derece zararlı yayınlar yapan bir kuruluştur. Yazar olayla ilgili değerlendirmelerine iki anı kitabında yer verir. O, Tan baskınını, henüz bir yıla varmayan yayın hayatında Büyük Doğu' nun gençliğe aşıladığı bilincin iptidai şekilde de olsa aksiyon haline gelmesi olarak düşünmektedir. Ona göre Tan gazetesinde karargâh kuran komünizma, Anadolulu ve kökçü üniversite gençliğinin pençesine düşmüştür. Baskının hiçbir resmî ve 1smarlama sevk ve idareye bağlı olmadan gençliğin öz vicdanıyla yapıldığı kanaatindedir. Olay sırasında gençler Büyük Doğu idarehanesinin önüne gelerek tezahürat yapmış, Necip Fazıl'ı pencereye çağırarak konuşmasını çılgınca alkışlamışlardır (Kısakürek, 2010: 269). Necip Fazıl bu görüşleriyle Tan gazetesini basan insanlara kendisinin önceden bir talimatının olmadığını ama bu insanları Büyü̈k Doğu dergisi vasıtasıyla fikren etkilediğini kabul etmektedir. İlginç bir şekilde zıt fikirlere sahip yazarlar bu olaya benzer tepkiler vermiş ve gazeteye yapılan baskını olumlu bir gelişme olarak değerlendirmiştir.

Necip Fazıl'ın olaydan önceki bir yazıdan dolayı oldukça üzüldüğünü anılarından okuyoruz. Aziz Nesin Tan'da yazdığı bir yazıda, Necip Fazıl'ın dindarlığıyla ilgili olarak mürşidi tarafindan yönlendirildiğini belirtir; şairden ve mürşidinden istihza ve hakaretle bahseder (Kısakürek, 2010: 269). Necip Fazıl bu yazıdan kısa süre sonra gerçekleşen Tan baskınında milliyetçi ve mukaddesatçı üniversitelilerin matbaayı paramparça etmesini, bir süre önce ölen mürşidinin ruhaniyetinin tecellisi olarak yorumlar (Kısakürek, 1998: 232). Olay, Türkiye'nin savaş sonrası olası bir Sovyet tehdidi altında kalması üzerine oluşan komünizm karşıtı hassasiyetin, komünizm sözcüsü görünen Tan gazetesi üzerinde öfkeye dönüşmesidir. Necip Fazıl Türkiye'nin sonraki on yıllarında devam edecek komünizm karşıtlığının gelişmeye başladığı yıllarda etkin bir rol oynamıştır. Burada devletin de Sovyetler Birliği tehdidinden dolayı komünizme zararlı bir ideoloji olarak baktığını eklemek gerekir. Saldırıyı, tek parti iktidarının üniversite gençliği eliyle gerçekleştirdiği, Sabiha Sertel'in ifadesiyle 'hükümet basını' ve köşe yazarlarının kışkırtıcı bir rol oynadığı (Acar, 2012: 19) eleştirileri vardır. Zekeriya Sertel'e göre olayda hükümetin rolü olduğu kesindir. Sertel, baskının Cumhurbaşkanı İnönü'nün bilgisi dahilinde ve Başbakan Saraçoğlu'nun verdiği emirle polis tarafindan tertiplendiğini ve yürütüldüğünü belirtir. Ayrıca göstericiler ve matbaaya saldıranlar arasında birçok sivil polisin olduğunu, saldırıyı onların yönettiğini, gösteriye katılan gençlerin ise üniversitedeki gerici ve faşist unsurlar olduğunu yazar (Sertel, 1968: 270-271). Necip Fazll'a göre hiçbir resmî sevk ve idareye bağlı olmadan gelişen olay, Sertel'e göre iktidar eliyle yapılmıştır. Bu iki ismin olayı değerlendirmesinde dikkat çeken daha önemli fark, kullanılan kelimelerdir. Necip Fazıl, olaya karışan ve destek verdiği gençler için "Anadolulu” ve "kökçü” sıfatlarını kullanırken aynı kişiler Sertel tarafindan "faşist" ve "gerici" olarak nitelendirilir. Bu ifadeler Türkiye'nin düşünce hayatındaki ayrışmayla ilgili mühim örneklerdir.

1940’lı yıllara dair anılardan dikkat çeken başka bir konu, şairin bağlı bulunduğu dergâhla ilgilidir. Necip Fazıl Kısakürek 1934 yılından itibaren Eyüp'te bulunan bir dergâha devam etmeye başlar. Burada şeyh olan Abdülhakim Arvasi ile tanışması, hayatındaki önemli olaylardan biridir. Şair, bu zâta büyük bir sevgi ve hürmet besleyecek, hayatını onun nasihatleri doğrultusunda şekillendirmeye çalışacaktır. 1943 yılında Necip Fazıl, mürşidinin gözaltına alındığını öğrenir. Gözaltından bir müddet sonra İzmir'e sürgün edilir. Sonunda milletvekili olan damadının 
çabalarıyla serbest bırakılır. Ankara'ya getirilen Abdülhakim Arvasi burada vefat eder (Kısakürek, 1998: 219-220-221-222). 1925'te ç1kan bir kanunla resmen kapatılan tarikat müesseseleri fiilen devam etmiş ancak bu olaydaki gibi zaman zaman takibata uğrayıp mensupları ve liderleri hakkında işlem yapılmıştır. Türkiye'de devlet ve toplum arasındaki gerilim sebeplerinden biri olan inanç kurumları üzerindeki baskı 1943’teki bu olayda da görülüyor. Katı laiklik uygulamaları ve kanunla kapatılmasına rağmen halkın dini eğiliminin neticesinde varlığını sürdüren tarikatlar cumhuriyet boyunca devam etmiş ve etkili olmuştur. Burada şu hususu belirtmek gerekir. Her ne kadar ilköğrenimini cumhuriyetten önce almiş olsa da modern bir eğitimden geçmiş ve büyük oranda seküler basın-edebiyat çevresi içinden çıkan bir sanatkâr olarak Necip Fazıl'ın tarikata intisap etmesi, devletin kültür ve eğitim politikalarına göre istenmeyen bir sonuçtur.

1940’lı yılların siyasi kişilikleri arasında akla gelen ilk isim İsmet İnönü'dür. Anılarının sonraki yıllara ait bölümlerinde çok sayıda siyasetçiye yer verecek olan Kısakürek, İsmet İnönü’den de bahseder; onun cumhurbaşkanı olduğu döneme ait değerlendirmeler yapar. Ancak yazar, İnönü'den detaylı şekilde söz etmez; bazı semboller üzerinden onun durumunu nakleder.

Anlattıklarına göre yerini aldığı zata ait, nerede ve ne şekilde heykel varsa o da aynını istiyor.

Meramı Taksim âbidesinin arka plândaki ikinci, üçüncü adamlar kadrosundan çıkmak, başı

doldurmak... Nitekim, işte banknotların üzerindeki eski resim de kaldırılmış ve yerine onun

kellesi oturtulmuştur. Selefine "Ebedî Şef" unvanının yakıştırılmasına karşılık ona "Millî

Şef” yaftası uygun görülmüş, fakat bu az gelmiştir. (Kısakürek, 2010: 255)

Yazar; İnönü'nün, Atatürk döneminden bazı sembolleri Atatürk'ün yerine kendisini koyarak yeniden kullanmak istediğini belirtiyor. İnönü kendini toplumda daha görünür kilmak ve iktidarını somut şekilde göstermek istemektedir. Devlet başkanına yönelik karizmatik bir imaj oluşturulmaya çalışılmaktadır. Necip Fazıl'ın değerlendirmesinde bu duruma açıktan bir tenkit görünmemekle birlikte satır aralarına sızan bir benimsememe tavrı anlaşılmaktadır. Yazar, İsmet İnönü'nün cumhurbaşkanı olduğu 12 yıl boyunca devam eden icraatı hakkında yorum yapmaz; hatırat kitaplarında kırklı yıllara ait sosyal ve siyasi konulara yer vermesine rağmen İnönü'den yukarıdaki alıntı ve birkaç anekdot dışında bahsetmemesi dikkat çekicidir.

1940’lı yılların siyaset ve ülke gündeminde en önemli konularından biri Demokrat Partinin (DP) kuruluşudur. Cumhuriyet Halk Partisi (CHP) içinde dörtlï takrir sonucu ortaya çıkan muhalefet, ayrı bir partinin başlangıcını oluşturmuş ve DP 1946'da kurulmuştur. Çok partili hayata bu defa kesin olarak adım atılır. Ülkenin çok partili hâle gelmesinde II. Dünya Savaşı sonrası dünya şartlarının ve ülke içinde tek partiden duyulan rahatsızlığın etkisi vardır. Yeni parti kurulmuştur ama ana kadrosu daha önce CHP'de görev almış isimlerdir. Necip Fazıl Kısakürek, DP'nin ana kadrosunun bu özelliğinden dolayı partiye ilk zamanlarında mesafeli yaklaşır.

Muvazaa partisi!.. Peşin bir pazarlık ve danışıklı dövüş işi olmasa bile, tabiatten, yaratılıştan muvazaa eseri olmaya mahkûm... Aynı kök ve ana gövdeye bağlı dallar arasında, biri şifalı, öbürü zehirli iki zıt meyva ve her birinin kendi verimini öbürüne karşı müdafaa imkân ve istidadı hayâl edilemez. (Kisakürek, 2010: 286)

Partinin kuruluşunda bunları düşünen yazar, birçok DP’liye karşı menfi fikirler besler. Sonraki yıllarda eleştirmekle birlikte irtibat kuracağı az sayıda isimden biri, parti kurulduğunda pek tanınmayan ama 1950 Genel Seçimleri sonunda başbakanlığa gelecek olan Adnan Menderes'tir.

1940’larda gerçekleşen başka bir siyasi atılım bu kez Necip Fazıl Kısakürek'ten gelir. 1949 Haziran'ında Büyük Doğu dergisiyle aynı adı taşıyan bir cemiyet kurar. Büyük Doğu Cemiyeti, kurulduğunda kendini bir parti olarak ilan etmez ama siyasi partiye evrileceğinin işaretleri muhtevasında ve hedeflerinde görülmektedir. Cemiyet çeşitli illerde şubeler açar. Anadolu'nun büyük mukaddesatçı kitlesini etkileme potansiyeline sahip olan cemiyet, Necip Fazıl'ın öncülüğünde toplumsal ve siyasal bir hareket olarak planlanmıştır. Ancak çeşitli nedenlerle 1951 yılında kendini 
fesheder. Necip Fazıl, Büyük Doğu Cemiyetini yıkan sebepleri kendi zaviyesinden açıklar. Bunlar kadro zaafı ve kurmay heyeti yoksunluğudur; Necip Fazıl bunun yanında kendisinin, Müslümanların gözünde küçük düşürülmesi için tertiplendiğini söylediği kumarhane baskınından söz eder. Yazar bu olayı komplo olarak değerlendirir ve komployu, "hürriyet" narasıyla gelip CHP’ye taş çıkartacak derecede yalan dolanda mütehassis insanların kurduğunu belirtir (Kısakürek, 2010: 301). Yeni iktidar olan DP’li bazı kişileri kasteder. Kumarhane baskınıyla ilgili suçlayacağı başka bir kişi Ahmet Emin Yalman olacaktır.

Anı kitaplarında sosyal hayatın bir parçası olarak edebiyat ve basına dair olaylara ve görüşlere de rastlanır. Türk edebiyat ve basın hayatı üzerine anılarını kaleme aldığı Bâbıâli kitabında birçok şair ve yazara yer veren Necip Fazıl, edebiyat ve basın hayatından rahatsızlık duymaktadır. Tanınmış bazı edebiyatçıların kişilikleri ve eserleri hakkında zaman zaman ağır eleştiriler yapar. Bâbıâlinnin sayfalarına hâkim olan düşünce, eleştirilen bu isimlerin pek çoğunun aslında köksüz ve Batı taklitçisi zayıf insanlar olduğu şeklindedir diyebiliriz. Necip Fazıl'a sırasıyla "genç şair", "mistik şair" ve "sabık şair" unvanlarını veren bu sanat ve basın çevresi, onun gözünde sahte tiplerin bolca bulunduğu bir alandır.

Dünya çapında fikir, sanat adamı çıkmadığı gibi, ahlâken de güvenilir, topluma müspet yönde model olacak yapıda insanlar çıkmamaktadır. Orası, Batı değerlerinin egemen olduğu, bir sosyal çürüme merkezidir. Necip Fazıl, Türkiye'deki kültür ve değerler dünyasından sapma ile Batı medeniyeti doğrultusundaki değişmenin kaynağı olarak, Bâbıâli'yi görmektedir. Çünkü, yazar, şair, sanatkâr, müzisyen, ressam vb. kültür ve sanat adamlarının kümelendiği yerdeki yöneliş, bütün toplumu etkilemektedir. Ülke çapında, olumlu yönde bir değişim olacaksa, bu öncelikle Bâbıâli'de müsbet bir gelişme ve dönüşümle olacaktır. (Arabac1, 2014: 127)

Bu tespitler, Necip Fazıl'ın ülke için zararlı gördüğü sosyal gidişatın önemli bir sebebinin sanat ve basın çevresi olduğunu göstermektedir. Yazarın bu çevreye yönelik değerlendirmeleri, kendisi de o çevrenin içinde edebiyata ve yayıncılığa adım attığı için ve Bâbıâli adını verdiği gazetecilik, dergicilik, yayıncılık ve edebiyat merkezini on yıllar içinde bizzat tanıdığı için dikkate değerdir. Onun tanıklığı; Türk basınının ve edebiyat hayatının, dönemi içinde cesur bir eleştirisini sunar.

\section{Sonras1 Sosyal ve Siyasi Muhteva}

1950 yılı Türkiye tarihinde bir dönüm noktası olarak birçok incelemenin başlangıç zamanı olarak kabul edilir. 14 Mayıs 1950 yllındaki genel seçimler sonunda 27 yıl süren tek parti dönemi sona ermiş ve Demokrat Parti iktidarı başlamıştır. 10 yıl sürecek bu iktidar dönemi, yine büyük dönüm noktalarından sayılan 27 Mayıs 1960 tarihindeki askeri darbeyle sona erer. Necip Fazıl Kısakürek'in DP iktidarı yıllarında bu partiye fazla değilse de Başbakan Adnan Menderes'e karş1 olumlu bir bakışı vardır. Birçok yönden eleştirilen tek parti yıllarından sonra DP iktidarı, ülke genelinde iyimser ve umutlu bir havanın oluşmasını sağlamıştır. Kısakürek'in bu partiye bir nebze yakınlığı, partinin, şairin ideallerine uygunluğundan değil, 1950 öncesine karşı duyulan karşıtllğın sonucudur. DP'nin ve Menderes'in Necip Fazıl Kısakürek tarafından kısmen benimsenmesinde bu partinin dine yaklaşımı da etkili olmuştur. Her ne kadar partinin ileri gelenleri daha önce tek parti yıllarında milletvekilliği yapmış olsalar da DP'yle birlikte halkın inanç hassasiyetlerine karşı 1950 öncesine göre daha iyi durumdadırlar. DP, dindar kitlelerle görece iyi ilişkilere sahiptir, bununla birlikte laiklik uygulamalarını tek parti yılları kadar sert olmadan devam ettirirler. "Demokratlar iktidara geldikten sonra, CHP'nin dinî duyguların ifadesi üzerindeki kısıtlamaları gevşetme ve Müslüman halkın duygularına ödün verme siyasetini sürdürdüler ama bir yandan da laiklik aleyhtarı eğilimlerle mücadele ettiler." (Zürcher, 2018: 270). Aslında çok partili siyasi hayat 1946'dan sonra kalıcı hale gelince CHP'nin de önceki yıllara göre dindar kesimlerle olan mesafesini azaltmaya çalıştı̆̆1 görülür; bu kitlelerden oy alabilmek için böyle bir politikaya gider. Ancak bu politika 
iktidarda kalmaya yetmeyecektir; partinin icraatları ve uzun yıllar içinde oluşan imajı ilk serbest seçimde partiyi iktidardan indirir. Necip Fazıl Kısakürek iki partinin bu durumu karşısında DP’ye ve Menderes'e yakın durur.

Yazarın anı kitaplarında sosyal ve siyasi konuların en çok işlendiği dönem 1950 sonrası yıllardır. Çok partili hayatın getirdiği imkanlar ve Necip Fazıl'ın etkisinin artması onu sosyal ve siyasal hayatın içine daha fazla çekecektir. Bu durum sadece ellili yıllarla sınırlı kalmamıs, vefatına kadar sürmüştür. Ellili yılların anılarında bahsi geçen önemli olaylardan biri Malatya Hadisesi olarak bilinen ve Necip Fazıl dahil birçok kișinin hapse girmesine neden olan suikast girișimidir. Olay Vatan gazetesi başyazarı Ahmet Emin Yalman'a 22 Kasım 1952'de Malatya'da gerçekleştirilen silahlı saldırıdır. Başbakan Adnan Menderes’in Malatya'da bulunduğu bir zamanda yapılan saldırıda Yalman yaralı kurtulur ancak olay Türkiye'de büyük bir yankı yapmıştır. Saldırının faili Hüseyin Üzmez dört gün sonra yakalanır. Üzmez, olayla ilgili yazdığı kitabında Necip Fazıl'ın ve Büyük Doğu'nun, üzerindeki etkisini detaylıca anlatır. Suikasttan sonra polise teslim olduğunda neden vurduğu sorulur. Üzmez, Yalman'nn Yahudi dönmesi olduğunu, ülke İstiklal Harbi'ndeyken Amerikan mandası istediğini, doğu isyanını körüklediğini, 1925'te İstiklal Mahkemesi'nde yargılandığında Yahudi olduğunu itiraf edip yaptıklarının ırkî cibilliyeti gereği olduğunu söylediğini, Atatürk'e kendisini affetmesi için yalvardığını ve güzellik yarışması düzenlediğini anlatır; eylemini bu nedenlerle gerçekleştirdiğini açılkar. Bu bilgileri Büyük Doğu'dan edindiğini belirtmek için "Necip Fazıl'ın Büyük Doğu'sunda okuya okuya ezberlemiştik." der (Üzmez, 1996: 159). Necip Fazıl, olayın kendisiyle ilişkilendirilmesinden endişe duymaktadır ve korktuğu başına gelir. Olayın üzerinden çok geçmeden Malatya Hadisesi sebebiyle, o sırada başka bir nedenle hapisteyken hakkında yeni bir tutuklama kararı çıkarılır ve Malatya Hapishanesi'ne sevk edilir (Kısakürek, 2018: 83). Kamuoyunda ve savcılık nezdinde Büyü̈ Doğu'daki yayınların, suikastçıyı azmettirdiği görüşü hakimdir. Bu görüşe delil sayılabilecek birçok yayın yapılmıştır. Necip Fazıl Kısakürek, Ahmet Emin Yalman’a yönelik oldukça ağır ve Yalman'ın şahsiyetini de hedef alan yazılar kaleme almıştır. Ona yönelik hakaret sayılacak ifadeleri vardır. 25 Kasım 1949 tarihli “Çıfıta Cevap!” başlıklı yazıda Yalman'ın Müslüman Türk memleketinde konuşamayacağı, onun bir dönme olduğu ve Sabatay Sevi’nin zakkum kanını taşıdığını yazar. Ayrıca İstiklâl Harbi'nde Amerikan mandasını savunduğu için Yalman'ın vatan haini olduğunu söyler. Bunlar yanında bahsi geçen yazıda daha başka hücumlar ve hakaretler vardır. Ayrıca yazının sonunda Yalman'a yönelik bir tehdit olarak algılanabilecek ifadeler geçer. "Elverir ki bir zamanlar, muazzez ve mübarek bir soydan gelen Ehl-i Sünnet gazetesinin ismet ve nezaket örneği sahibine yaptığın ve bütün zayıf Müslümanlara tevcih ettiğin gibi, hakikatte bize değil, Allah'a ve Resûl'üne düşman olan suikastçı kalemini (Büyük Doğu) ya yöneltmek cesaretini göstermeyesin ve hesabını görecekleri güne kadar menfur ve melûn köşende "sus, pus" oturasın!.. Sen bilirsin, tercih hakkını sana birakiyoruz." (Kısakürek, 1992: 121-124). 23 Şubat 1951 tarihli "Ahmet Emin Yalman" başlıklı yazıda ise "dönmelere başkanlık, masonlara çığırtkanlık vazifesiyle mükellef" saydığ1 Yalman’1 “din, mukaddesat, Türklük ve birlik düşmanı” (Kısakürek, 1992: 125) olarak nitelendirir. Doğrudan hakaret içeren bir başlığa sahip yazısı 30 Mart 1951 tarihli "Deyyus!" yazısıdır. Necip Fazıl bu yazıda hakaretlerine devam eder ve kendisine yönelik kumar komplosunun tertipleyicisi olarak Yalman'ı gösterir. Onun irtica yalanı uydurduğunu, Konyalı Müslümanlara iftira attığını belirtir. Yalman'ın hüviyet ve mahiyetini teşhir edeceğini söyleyen yazar, onda zerre miktar haysiyet varsa intihar etmesi gerektiğini söyler (Kısakürek, 1992: 126-127). Malatya Hadisesi'nin olduğu 1952 yllındaki yayınlarda ise günlük olarak çıkan Büyük Doğu gazetesinde tehdit sayılacak ifadeler daha da artacaktır. Gazetenin 20 Haziran 1952 tarihli sayısında "Beynelmilel Münafik Yalman'a" başlıklı bir yazı yer alır. Abdurrahman Şeref Laç imzalı yazıya göre Yalman; DP, Türk'ü Allah'a yaklaştırdıkça bu partiye diş bilemeye başlayan biridir. Biri Anadolu'da Allah dese irtica yaygarası koparmaktadır, Menderes irtica yok dediğinde ona tavır almıştır. Yazıda ayrıca Yalman'ın masonluk, Yahudilik ve kozmopolitlik emrinde biri olduğu belirtilir, onun Amerikancı olduğu söylenir. Tehdit sayılacak ifadeler de görülür. Yalman'a hitaben: "Evet, senin tâbir ve ikrarınla, biz, 
senin boynuna kement atan "cellâd" olacağız." ve "Bizden kork ve korkundan geber." cümleleri yer alır (Laç, 20.06.1952: 1 ve 5). Ahmet Emin Yalman'dan birçok yerde "Vatan satıcısı" olarak bahsedilir. 9 Temmuz 1952 tarihli gazetede yer alan bir haber Vatan'ın düzenlediği güzellik yarışmasıyla ilgilidir. Büyük öfkeye neden olan yarışmayla ilgili haberde bir de fotoğraf yayınlanır. Yazının sonunda: "Biz de resmen ve alenen taahhüd ediyoruz ki Türk kızlığına edilen bu iftiranın intikamını nasıl alacağımızı pek yakında göreceksiniz!!’” yazar (B̈̈yǚk Doğu, 09.07.1952: 1). 2 Ağustos 1952 tarihli gazetede Abdurrahman Şeref Laç bu kez savcıyı görece çağırır; Yalman'ın, kamuoyunu telaşa ve heyecana sevk eden, milli menfaatlere müthiş zararlar verecek mahiyette yazılar yazdığını belirtir. Bunun bir suç olduğunu ekler (Laç, 02.08.1952: 1). Gazetenin ağustos ayındaki bir başka sayısının okuyucu mektuplarına yer veren sütunundaki mektuplardan biri gazeteyi zor durumda bırakacak niteliktedir. N. Turgut Özdemiroğlu imzalı, Malatya'dan gönderilmiş mektupta Yalman'a hitaben "Yalnız şuna şaşıyoruz, nüfusu 1 milyonu aşkın bir Türk şehrinde nasıl yaşıyor, nasıl yaşatıllyorsun, hayret!" ifadeleri geçer (Özdemiroğlu, 12.08.1952: 3). Görüldüğgü gibi Büÿ̈lk Doğu'nun yayınlarında basın yoluyla tehdit ve hedef gösterme sayılacak ifadeler çokça yer almıştır.

Vatan gazetesi ise suikast olayının ardından Necip Fazıl Kısakürek’i zan altında bırakacak haberler yapar. Gazetenin 25 Kasım 1952 tarihli sayısındaki bir haberde Malatya Hadisesi'yle ilgili tahkikatın İstanbul'a da intikal ettiği ve aralarında Büyük Doğucu bazı önemli isimlerin de bulunduğu kişilerin tutuklanmasının beklendiği yazılır. Aynı haberde Necip Fazıl Kısakürek'in, demokratik nizamın müsamahakârlığından yararlanarak Büyük Doğu isimli bir gazete çıkardığı ve zararlı yayınlar yaptığı anlatılır. Vatan gazetesine göre Büyük Doğı'nun yayınları mürteci zümreleri Ahmet Emin Yalman aleyhine sürekli tahrik etmiş, onun öldürülmesi gerektiğini bu zümreye telkin etmiştir. Neticede Malatya'da bu tahrikler karşıllk bulmuş ve suikast gerçekleşmiştir ( $V$ atan, 25.11.1952: 5). Vatan, olayın ardından günlerce konuyu gündemde tutar ve Necip Fazıl Kısakürek'in suikastta rolü olduğunu ispata çalışır. 3 Aralık 1952 tarihli sayıda Necip Fazıl kastedilerek "Sahte mürşit suikastı nasıl tahrik etmişti?" (Vatan, 03.12.1952: 5) başlıklı bir haber yayınlanır. Ertesi günkü sayıda ise "Necip Fâzıl'ın Tevkîfi Lâzımdır" başlıklı bir haber yer alır. Başlığın altında "Bir hukuk bilgini, sahte mürşidin suikast hadisesindeki hukuki durumunu belirtiyor." cümlesiyle Necip Fazıl'ın tutuklanması gerektiği üzerine yayın yapılır (V atan, 04.12.1952: 1). Neticede yazar, olayla fiilen hiçbir ilişkisi olmamasına rağmen tutuklanır.

Malatya Hadisesi'nin arka planında, Vatan gazetesi sahibi ve başyazarı Ahmet Emin Yalman'ın faaliyetlerinin milliyetçi ve mukaddesatçı çevrelerin büyük tepkisini çekmesi yatmaktadır. Basında da Büy ük Doğu ve V atan gazeteleri arasında ciddi bir gerilim vardır.

Büyük Doğu, kısa bir zaman içinde Bâbıâli’nin “efe gazetesi” olur; düşmanlarının başında ise Ahmet Emin Yalman'a ait "Vatan” gazetesi vardır. Yahudi-Dönmelerin iş gördüğü bu tezgâhın, Türk ruh ve ahlâkını bozmayı hedef tutucu bir gâyeyle bir güzellik müsabakası tertiplemesi üzerine, gazetesinde karşı bir kampanya başlatır ve tirajı 80 bin olan Vatan gazetesini, gazete bayilerinde satılamaz hâle getirir. (Ak, 2016: 108)

Necip Fazıl'ın basındaki bu etkisi, cesur ve polemikçi bir ses olması, onu hadisenin içinde göstermiştir. Necip Fazıl'ın düşüncelerinden ve yayın politikasından rahatsız olanlar için bu olay büyük bir firsat olur. Yazar defalarca girdiği hapse bir kez de bu olay yüzünden girer.

Ahmet Emin Yalman’a yönelik suikast girişimi, Türkiye'de çok partili dönemin ilk yıllarında yaşanan siyasi bir olaydır. Ülkede ezici çoğunluğa sahip muhafazakâr kitlelerle çağdaşlık taraftarı Batıcı çevrelerin, basının sembol bir ismi üzerinden karşı karşıya gelmesidir. Hadise, cumhuriyet tarihi boyunca "irtica tehdidi” söyleminin dile getirildiği çok sayıdaki olaydan biri hâline getirilmiştir. Adnan Menderes'in başbakan olarak muhafazakâr çevrelerle arasının iyi görünmesi, meseleyi daha dikkat çekici hale getirir. 
1951 y1lının ilk aylarından itibaren mukaddesatç kitleye yakınlık gösteren Adnan Menderes’i çevrelemek için çaba gösteren irtica yaygaraciları, nihayet netice devşireceği bir imkan kazanır. Onlara göre, suikast, Yalman'ın şahsında Türk inkılâbınadır! Atatürk ilkelerini, çağdaş uygarlığ1 ve özgürlüğü hedef tutmaktadır! Dizginleri gevşetilen gericiliğin nerelere kadar varacağını gösteren canlı bir misaldir! (Ak, 2016: 111)

Tan gazetesine yapılan saldırıda komünizm karşıtı hassasiyet söz konusuyken burada liberal görüsslere sahip, ABD ile ilişkileri olan bir gazeteci hedef alınmıştır. Necip Fazıl'ın Tan ve Vatan gazetelerine muhalefeti sol ve komünizm karşıtlı̆̆ yanında, zararlı olduğunu düşündügü başka fikir ve girişimlere de yazılarıyla tavır aldığını gösteriyor. Her iki olaya karışan gençlerin Necip Fazıl'ın yazılarından ve yönettiği Büyük Doğu'daki diğer yazılardan aldıkları motivasyon, yazarın okurları üzerindeki etkisinin kanıtıdır. Ancak bu etkinin olumsuz sonuçlara yol açtı̆̆ına dair bir değerlendirme vardır. Necip Fazıl ve yönettiği Büyük Doğu’nun dili, provokatif, kitleleri harekete geçirecek kadar kışkırtıcı ve şiddet dolu olmasıyla eleştirilmiştir ve Tan Gazetesi Baskını ile Malatya Hadisesi'nin, bu dil ve üslubun en ses getiren neticeleri olduğu (Üstün, 2011: 81) düşünülmektedir.

Ellili yıllardaki dikkat çekici olaylardan biri de Ticanîlik tarikatının eylemleridir. Grup, adını ilk kez 1949'da Türkçe ezan uygulaması devam ederken Meclis'te Arapça ezan okuyarak duyurur. Daha sonraları Atatürk heykellerini tahrip etmeye başlamışlardır. Ticanî lideri Mehmet Pilavoğlu ve müritleri heykellere yönelik eylemlerin ardından mahkûm olurlar, Necip Fazıl Kısakürek ile bir müddet aynı hapishanede kalmışlardır. Necip Fazıl bu şahısla ve tarikatıyla ilgili görüşlerini hatıratında anlatır. Yazarın Ticanîlerle ilgili kanaatleri olumsuzdur. Hapishanede gördüğü bu kimseleri, başta İlahî hudut olmak üzere had ve hudut inceliği tanımayan şaşkınlar, batıl şekilde kendi kendilerinden geçmiş sapıklar, korkunç derecede bilgisiz, anlayışsız ve zevksiz insanlar olarak vasıflandırır. Bu insanlar yüzünden o zamanın din düşmanlarına birtakım yalancı kıyas unsurları verildiğini düşünür. Yazar bu görüşlerine rağmen onların yıllarca hapis cezasına çarptırılmasına üzülmektedir. Necip Fazıl, onlarla arasındaki büyük idrak farkına rağmen ne de olsa "Allah" diyen bu gruba karşı daha önce gazetede yaptığı "Halk Partili Ticanîler mahkûm oldu." şeklindeki haberden dolayı cezaevinde tanıştığ Ticanîlerden af dilemiştir (Kısakürek, 2018: 189). Ticanîlerin Halk Partili olduğuyla ilgili başlık oldukça ilginçtir. Atatürk heykellerine saldırmış insanların CHP ile alâkası anormal görünen bir durumdur. Ancak durum CHP'nin, 1950 seçimleri yaklaşırken DP’ye gideceği görülen mütedeyyin vatandaşların oylarını alabilmek için yaptığı pragmatik hamlelerden biridir. Yakup Kadri Karaosmanoğlu, bu türden hamlelerden biri olarak seçimlere yakın günlerde Ticanî tarikatıyla iş birliği yapıldığından bahseder (Karaosmanoğlu, 2018: 160). Olay, siyasi partilerin seçimlere giderken seçmenleri etkilemek için başvurduğu tipik taktiklerden biridir.

Malatya Hadisesi ve Ticanî tarikatının eylemleri birlikte düşünüldügünde DP iktidarının ilk yıllarında inkılâpçı ve laik çevreleri endişelendiren bir ortamın meydana geldiği düşünülebilir. Nitekim dini temelli görülen bu olaylar, laik rejimi tehdit altında gösteren bir zannın oluşmasına zemin hazırlamıstır. Olaylar uzun süreye yayılmamış ve münferit kalmıssa da sembollere yönelik saldırılar olmasıyla rejim açısından tehlike olarak değerlendirilmiştir. Necip Fazıl Kısakürek bu iki olayı başka bir açıdan değerlendirir. Ona göre olaylar inançl insanları zor durumda bırakmıştır. "Bizim idare etmediğimiz ve tanımadığımız gençler, Ahmet Emin'i öldürmeye kalkarak bu davâyı ve onun zafer talihini bir an için zedelediler. Pilâvoğlu'nun idare ettiği insanlarsa, kendisinin bilgisi ve emri altında veya değil, zatiyle günahsız ve mes'uliyetsiz birtakım tunç parçalarına saldırıp, görülmemiş kanunlar çımasına sebep oldular.” (Kısakürek, 2018: 193). Sözü edilen görülmemiş kanun, heykelleri tahrip sonrası ihdas edilen Atatürk'ü Koruma Kanunu'dur.

Yazarın ellili yıllarla ilgili anılarında DP önemli bir yer tutar. Necip Fazıl Kısakürek’in DP ile ilişkileri kişilere göre farklılıklar göstermektedir. Yazar bu partiyi, önceki devreye göre daha iyi görmekte ama ideal bir hareket olarak düşünmemektedir. Partideki birçok şahsiyet hakkında görüşleri olumsuzdur. İki önemli isimden Celal Bayar'a karşı menfi iken Adnan Menderes'e karşı 
müspettir. Büy ̈̈k Doğı' nun 1952'de gazete olarak çıkıp bir müddet sonra kapatılmasına sebep olan hadise, Necip Fazıl'nn, devletin zirvesindeki bu iki isimle ilgili kanaatinin altındaki nedenlerden biridir. Menderes'in desteğindeki gazete yayın hayatına devam ederken Ankara'ya çağırılan Necip Fazıl, DP'li siyasetçi Samet Ağaoğlu'ndan gazeteyi kapatması talimatı alır. Bunun bir politika icab1 olduğu söylenir. Necip Fazıl, Başbakan Menderes'in desteğine rağmen iktidardan birinin kendisinden gazeteyi kapatmasını istemesinin arkasındaki kişiyi fark eder. Büyük Doğu'nun kapanmasını isteyen kişi Cumhurbaşkanı Celal Bayar'dır. Kısakürek'e göre "DP kumaşının baş yaması" olan Celal Bayar, "kumaşın asli dokusu olması gereken" Menderes'e emir vermiş ve "gericinin sesinin kesilmesini, ona yardımdan vazgeçilmesini" istemiştir. Necip Fazıl hadiseyi naklettikten sonra DP'nin işleyişiyle ilgili mühim bir yorumda bulunur. Bayar-Menderes ikilisi arasındaki iktidar çekişmesi hakkında Menderes’in, iktidarın en başından beri Bayar'a "ya sen ya ben" demesi gerektiğini ama bunu diyemeyip iradesini Bayar'a teslim ettiğini belirtir. Menderes'in her uyarıda boyun eğdiğini söyleyerek onu eleştirir (Kısakürek, 2010: 308). Necip Fazıl'ın Celal Bayar'la ilgili menfi düşüncelerine sebep olacak başka bir olay bir vekiller heyeti toplantısında yaşanmıştır. Tevfik İleri'nin naklettiği bu olay Tevfik İleri ve Celal Bayar arasında geçen bir konuşmadır. Tevfik İleri "kendi gençliğimiz" dediği kitleyi hükümet olarak boğmalarının yanlış olduğundan söz eder. Bu gençliğe sahip çıkılması gerekliydi diyerek gençliğin CHP’ye karş1 varlığının öneminden bahseder. Bunun üzerine Bayar sözü edilen gençliğin CHP'ye karşı olduğu her noktada CHP ile beraber olduğunu söyler. Necip Fazıl DP'yi yıkacak olan şeyin, onun aslî kumaşıyla baş yaması arasındaki tezat olduğunu söyler (Kısakürek, 2010: 315). Aslında Celal Bayar ve Necip Fazıl Kısakürek arasında daha önceki yıllarda olumlu denebilecek birkaç temas olmuştur.

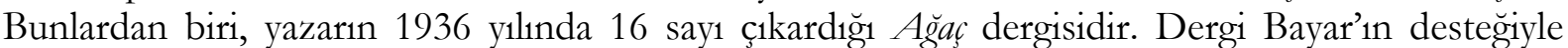
çıkmışır. 1943 yılında ise Büyüle Doğu çıkmaya başlayınca Necip Fazıl, Celal Bayar'a, "Aksiyonumuzu kendisine bağlayacağımız bir devlet adamı aramaktayız." der ve ona Büyük Doğu davasının siyasi liderliğini teklif eder. O dönem 60 yaşında olan Celal Bayar, cevap olarak siyasi hayatını bitirmiş bulunduğunu söyler. Oysaki iki yıl sonra Demokrat Parti'yi kuracaktır (Yürekli, 2014: 678-679).

Bayar, Necip Fazıl'ın faaliyetlerine engel çıkarırken Menderes'in destek verdiği görülür. Ancak Başbakan'ın, Necip Fazıl ve Büyü̈k Doğı'ya yönelik alâkası ve destekleri sürekli değil, düzensizdir. Yazar, Menderes'i Büyük Doğu fikriyatına hizmet edecek bir vaziyete getirmeyi hedeflemisstir. Menderes'in iktidarda olması, bir firsat olarak düşünülmüş de olabilir.

Necip Fazıl'ın gözünde Menderes, "bu vatanın şiddetle muhtaç olduğu ve en hassas dakikada bașinda bulduğu ender zekâ ve ruhlardan biridir!" Onu Demokrat Partiden ayrı tutar ve büyük bir inkılâp hareketinin hasretini, Menderes’in şahsiyetine bağlı görür. Menderes'e bağlı bu politikasının, kendisinin Menderes tarafından kullanıldığı şeklinde yorumlanmasına kiymet vermez. Muhatabını kendi davâsına çekmek maksadıyla ciltler dolusu yazı kaleme alır. (Ak, 2016: 107-108)

Aslında Adnan Menderes, Necip Fazıl Kısakürek’in özlemini çektiği ve uğrunda çabaladığ1 ideallere yakın biri değildir. Bununla birlikte onun tek parti yıllarını bitiren partinin başbakanı olması ve ülkedeki mütedeyyin insanlara yakın bir politik imaja sahip olması, Necip Fazıl'ın gözünde Menderes’i değerli yapmış olmalıdır. Ayrıca icraatının ilk yıllarında başarılı işler çıkardı̆̆ını da söylemek gerekir. (Bütün icraatı içinde bilhassa ezanın aslî haline döndürülmesi Menderes’e büyük bir itibar kazandırmıştır.) Yazarın Menderes tarafından kullanıldığı düşüncesi ise eksiktir. Nitekim bu karşılıklı bir destektir. Menderes basında Necip Fazıl gibi etkili bir kalemi yanına çekmiş ama Büyǚ Doğu da örtülü ödenekten -düzensiz de olsa- yararlanmıştır.

Yazar, 10 yıl süren DP iktidarını üç devre hâlinde özetler. Birinci devre, 1954 seçimlerine kadarki dört yıllık süredir ve bu dönem hedefsiz gayret devresidir. İkinci devre, 1957 seçimlerine kadarki üç yıllık dönem ve boşuna zahmet devresi, üçüncü dönem ise 1957'den 27 Mayıs 1960'taki 
darbeye kadarki boyuna gaflet devresi. Yazar bu dönemlendirmeyi yapar ama bunun riyazi olduğunu, aslında DP devrinin çok ayrıntılı çizgilere sahip bulunduğunu belirtir (Kısakürek 1970: 189). Görüldüğü gibi Necip Fazıl DP’yi hiçbir döneminde başarılı saymamaktadır. Dönemlere verdiği isimlerde bilinçsiz ve istikameti olmayan, yanlışlıklar içinde bir parti tasviri vardır.

27 Mayıs'tan birkaç gün önce Necip Fazıl Kısakürek ve Adnan Menderes Başbakanlıkta görüşürler. Tevfik İleri bu randevuyu almış ve Necip Fazıl Kısakürek’le birlikte görüşmeye gitmiştir. Gizli tutulması için sabah saat altıda randevu verilmiştir. Görüşmenin öncesindeki günlerde hükümet karşıtı öğrenci olayları yaşanmış, Harp Okulu öğrencileri gösteri düzenlemiştir. Başbakan, Necip Fazıl'a bu konular hakkındaki görüşlerini sorar. Cevabı, keskin bir çözüm önerir.

Hükûmet kuvvetlerine karşı fiille karşı duran Halk Partisi sevk ve idaresindeki sözde gençlik yığınından bir buçuk ölü yerine 150 ölü verdirilseydi ortada bir hükûmet bulunduğu anlaşılır ve hiçbir şey olmazdı. Avrupa'nın nice (demokratik) ülkesinden bin bir misal... Demokrasi, kanunları çiğneyen ve hükûmete el kaldıran zümrelere şefkatle mukabele etmek değildir. (Kısakürek, 2018: 272)

Necip Fazıl, gösteriler karşısında devletin gücünü göstermesini ve bu uğurda çok sayıda vatandaşın ölmesinin göze alınmasını düşünür. Devletin meşru şiddet kullanma yetkisini sonuna kadar kullanmasından yanadır. Bu sözlerde hükümete olaylar karşısında pasif kaldığı eleştirisi görülür. Harp Okulu öğrencilerinin yürüyüşlerinin de askeri edebin gerektirdiği şekilde cezalandırılmasını, elebaşlarının rütbelerinin sökülüp ordudan atılması gerektiğini anlatır. Muhalefet için lazım olanın ise ihtilâl hazırladıkları ithamıyla partilerinin kapatılması olduğunu söyler (Kısakürek, 2018: 272). Necip Fazıl çok sert tedbirler önermektedir. Görüşmede ayrıca DP'nin nasıl bir tasfiyeye ihtiyaç duyduğu ve partinin nasıl düzeleceği üzerine görüşlerini açılar. Yazar DP’yi, Halk Partisinin basit sslahatçı bir şubesi olmaktan çıkarmak gerektiğini, ona tam manasıyla ve kökten aykırı bir dünya görüşü olarak milliyetçi ve özcü bir grubu partide hâkim kılmak gerektiğini anlatır. DP'nin maddi imardan önce ruh kalkınmasına yönelmesini, bunun ideal sahibi insanlarla gözü kara şekilde yapılmasını ve istinadın millete olmasını muhatabına iletir (Kısakürek, 2018: 272273). Necip Fazıl'ın DP'nin çıkış yolu için yaptığı bu teklifleri uygulamaya vakit kalmamış ve görüşmeden birkaç gün sonra 27 Mayıs Darbesi gerçekleşmiştir. Yazar, ülkedeki durumun vahametini fark etmiş olmalı ki Menderes'le görüşmesinde ona bir ihtilâlin açık şekilde yaklaştığını, bu duruma karşı hiçbir şey yapılamayacaksa 40-50 kişilik bir kadro halinde uçakla ülkeden kaçmasını tavsiye eder (Kısakürek 2018: 274). Görevi başındaki Başbakan’a, ekibiyle ülkeden kaçmasının söylenmesi 27 Mayıs öncesi durumu açıklamaktadır. Nitekim Necip Fazıl'ın öngörüsü çıkmıss ve DP kadroları darbeden sonra yüzlerce sanık hâlinde Yassıada Mahkemeleri’nde yargılanmıstır.

27 Mayıs 1960’taki darbe bir cunta tarafindan gerçekleştirilmiştir. Cumhuriyet tarihinin ilk askeri müdahalesidir. Dolayısıyla vatandaşlar daha önce böyle bir olayla karşılaşmamıştır.

Askerlerin yönetime el koyuşu, Ankara ve İstanbul'daki halk, bilhassa her iki kentteki büyük öğrenci kitlesi ve genelde aydınlar arasında büyük bir sevinçle karşılandı. Ülkenin geri kalanı ise bu türden bir tepki göstermedi. Kırsal kesim hayra alâmet sayılmayacak şekilde sessiz kalmıştı. Önceki aylarda yaşanan karışıklıklar neredeyse yalnızca Ankara ve İstanbul'la sınırlıydı. Başka yerlerde halkın Menderes'e olan sevgisinde ani bir düşüş olduğunu doğrulayacak bir gösterge de yoktu. (Zürcher, 2018: 279)

Halkın olaya karşı aldığı tavır hakkında iki büyük şehirdeki birtakım insanların darbeyi desteklediği görülüyor. Ülke genelinin ise olaya yaklaşımı sessizlik olmuştur. Ülkede DP’ye yönelik, darbeyle indirilmesine destek olacak kadar büyük bir rahatsızlığın olmadığını, bunu dar bir çevrenin istediğini anliyoruz.

Ordunun emir komutası dişında gerçekleştiği için ilk günlerde darbeyi gerçekleştiren subayların ne yapacağı belirsizdir. Günler geçtikçe hukukçu akademisyenlerin de yardımlarıyla darbe 
sonrası yol haritası ve DP'lilerin durumu ortaya çıkmaya başlar. Necip Fazıl Kısakürek bu müdahalenin zayıf bir hükümete karşı yine zayıf bir cuntadan geldiğini belirtmek için "Yoğurttan bir hükûmete mukavvadan bir hançer saplandı." (Kısakürek, 1973: 17) cümlesini kullanır. Yazar bunu söyler ama 27 Mayıs'ı yapanlar zayıf ve fikirsiz bir kadro gibi görünse de darbenin sonuçları Türkiye'de köklü değissimlere sebep olur. Yeni bir anayasa hazırlanır, beraberinde yeni anayasal kurumlar ortaya çıkar. Ülkeyi on yıl yönetmiş iktidar yargılanır; 15 idam cezası verilir, bir başbakan ve iki bakan idam edilir. Çok sayıda insan farklı sürelerde hapis cezaları alır. Necip Fazıl Kısakürek, Yassıada'da kurulan mahkemede DP dışında yargılanan isimlerden biridir. Örtülü ödenekten dolayı yarg1lanan Kısakürek, savunmasında DP döneminde örtülü ödenek aldığını ama bunu bir rejim ve hükümet meddahlığı görevi için almadığını anlatır. Menderes'in örtülü ödenek yardımını, davası için kabul ettiğini söyler. Ancak bu yardımın sürekli olmadığını belirten Kısakürek, kendisine gösterdiği yarım, devamsız ve samimiyet derecesi belirsiz alâkadan dolayı o sırada mahkemede sanık olarak bulunan Adnan Menderes'e minnettarlığını bildirir (Kısakürek, 2018: 288-289).

Necip Fazıl Kısakürek, 27 Mayıs Darbesi'nde hiçbir olumlu yön görmez. Darbeyi gerçekleştirenleri cahil bir güruh olarak nitelendirir.

27 yıllık Halk Partisi idaresinin gönüllerde beslediği gizli hıncı ve onun kötülükler tablosunu farkına varmadan Demokrat Partiye çevirip asıl mesullerini görmeyen ve işi Halk Partisi yararına döndüren yüzde yüz fikirsiz ve bilgisiz hareket... Niçin geldiğini bilmediği için neden gittiğine de cevap bulması imkânsız, devlet mekanizması üzerinde bütün anlayışı, Afrika sahillerine düşmüş bir gemiyi ağızlarında bıçaklar, işgal eden bir kabilenin, pusla, dümen ve makine bilgisi derecesinde bir ham kuvvet nümayişi... (Kısakürek, 2010: 316)

Yazar tek parti döneminde muhaliftir. DP'yi iktidar yıllarında zaman zaman eleştirmiştir, sonrasında idareyi ele alan Millî Birlik Komitesi için de olumsuz görüşlere sahiptir. Onun idealindeki idare, sonraki yıllarda da bir türlü oluşamayacaktır. Necip Fazıl Kısakürek aslında rejim karşıtı dünya görüşünün de etkisiyle ülkede iktidar olmuş farklı zihniyetlere mensup hiçbir yapıya tam manasıyla bağlanamayacaktır. Bu bağlanamayışta yazarın kendine olan güveni ve okurları nezdindeki "üstat" mevkii de etkilidir. Çünkü Necip Fazıl; birikimi ve saygınlığılla siyasi partilere, iktidarlara tâbî olacak bir kişilik değildir, onlara yol gösterecek bir konumda yer almaktadır. Türkiye'deki milliyetçi ve mukaddesatçı çevreler içinde onun yol gösterici ve öncü vasfı oldukça belirgindir.

Yazar, 27 Mayıs'tan önce ülkenin lehine olacağını düşündüğü başka türlü bir ihtilal beklemektedir. Bu ilginç fikrini anılarında anlatır. Beklediği ve özlediği ihtilal DP’ye ve onun arkasındaki Halk Partisine karşı olacak, bu şekilde Demokrat Parti halisleri de kurtulacaktır. 27 Mayıs Darbesi'ni ilk duyduğunda önce Adnan Menderes'in devlet içinde bir devlet darbesi yaptırdığını düşünür ve sevinir (Kısakürek, 2010: 320). Bir süre sonra yanıldığını anlayacaktır. Yazar bir yandan Menderes’i Bayar karşısında zayıf kalmakla eleştirir ama aynı zamanda ondan kendi partisini temizlemek adına böyle bir hareket bekler. Cumhurbaşkanının ve zaman zaman kendi parti grubunun baskısı altında kalan bir Başbakan'ın bunu yapabileceğini düşünmek makul bir beklenti değildir.

Necip Fazıl'ın 27 Mayıs'la ilgili naklettiği başka bir husus Alparslan Türkeş hakkındadır. Darbeye albay rütbesiyle katılan Türkeş, bu işin içinde olmasının nedenini Necip Fazıl'a daha sonra anlatmıştır. Türkeş, cuntaya sonradan katıldığını, amacının, ihtilâlin Halk Partisi yararına bir yön almasını engellemek olduğunu belirtir. Kurulmuş bir tertibi dağıtamayacağına göre bu tertibin ters bir istikamete saptırılmaması fikriyle cuntaya dahil olduğunu anlatır (Kısakürek 2010: 321). Necip Fazıl'ın ihtilâl beklentisinde ve Alparslan Türkeş'in gerçek bir darbenin içinde bulunmasındaki ana sebep Halk Partisi karşıtlığıdır. Türkiye'deki sağ hareketler için önemli kişiler olan iki isim de CHP aleyhtarlı̆̆ında benzer görüştedir. 
27 Mayıs'taki darbenin ardından iktidardan düssen DP'nin devamı Adalet Partisi (AP) olmuştur. Ragıp Gümüşpala'nın başkanlığında 1961'de kurulan parti, koalisyonlar ve tek başına iktidarlar olmak üzere uzun yıllar iktidarda kalır. Necip Fazıl Kısakürek bu partinin hikâyesine dair düşüncelerini nakleder. Onun gözünde AP birçok olumsuz özelliğe sahiptir. Yazar bu partiyi, ordunun siyasetteki etkisini kıramamak, ekonomide, eğitimde, sosyal hayatta başarısız olmak bakımından eleştirir; AP'nin, DP'nin yapmaya memur olup yapamadığı işleri kendisinin yapması gerektiği hikmetinden uzak olduğunu söyler. Partiyi suçladığ1 önemli olaylardan biri 12 Mart 1971'deki Genelkurmay muhtırasına ses çıkaramayışıdır (Kısakürek, 2010: 325-326). Muhtıradan sonra Başbakan Süleyman Demirel istifa etmiş, bu olay ordunun 27 Mayıs 1960'tan sonra bir hükümete karşı en ağır müdahalesi olmuştur. Necip Fazıl Kısakürek, AP'den ayrılanların kurduğu Demokratik Parti hakkındaki değerlendirmesinde bu partiye de sicak bakmaz. Demokratik Partinin, Adalet Partisinden üzerine devşireceği milli 1stırap ve inkisara mihrak olmak mânasını aktaramadığını, bir lâhika, kör bağırsak mevkiine düştüğünü (Kısakürek, 2010: 327) belirtir. 1970’lerin Türkiye'sinde Adalet Partisi iki büyük partiden biriyken (diğeri Cumhuriyet Halk Partisi) Demokratik Parti pek varlık gösterememiş ve sağ seçmenin teveccühünü kazanamamıştır.

Yazarın bu yıllara ait hakkında yorum yaptı̆̆ diğer parti, Milli Nizam Partisinin devamı olan Milli Selamet Partisidir (MSP).

Kendisine kadar hep dış ve sahte hakikatlerden gelen partilere karşılık, ilk defa iç ve som hakikatten yola çıkmanın temsilcisi; fakat bu temsilin telif hakkına, büyük idrakine ve üstün (strateji)sine henüz uzak... Kadrosunda en halis ve katıksız, katışıksız, ama teçhizatça zaif insanların yuvalandığı bu parti, bizim 30 küsur yıllık çırpınıșımızın, kendi başına ve kendi kendisine mahsülüdür; ve bu bakımdan, aramızda, ister istemez bir sütnene ve çocuk münasebeti vardır. (Kısakürek, 2010: 327-328)

Necip Fazıl'ın MSP hakkındaki bu görüşleri, onun siyasi partiler arasında en çok bu partiye yakın olduğunu gösterir. Yazar ve parti, İslamcı görüşleri benimsemeleri bakımından yakın fikriyata sahiptir. Ancak hatıratındaki değerlendirmeler, MSP'yle ilişkilerinin bir yönünü açıklar. Yazar 1970’li yılların gerilimli sosyal ve siyasî ortamında bir süre sonra bu partiyle anlaşmazlığa düşecektir. MSP'den uzaklaşmasının altında yatan nedenler partinin işleyişi, CHP ile yaptığ koalisyon, yolsuzluk iddiaları ve partinin önde gelen isimlerinin Necip Fazıl'ı oyalama taktikleri şeklinde özetlenebilir. 1977'den itibaren Milliyetçi Hareket Partisi'ne yakın duran Kısakürek, milliyetçi camiada bulunduğu için gocunmaz. İslami çevrelerin yoğun eleştirilerine rağmen 12 Eylül'e kadar Milliyetçi Hareket’in içinde yer alır (Çağan, 2013: 93-95). Yazar Türkiye'nin en zor on yllı olan yetmişli yıllarda siyasetin fiilen dışında olmakla birlikte milliyetçi ve İslamcı partilerle ilişkiler içindedir. Ancak hiçbir partiyi tam olarak benimseyememiştir. Bununla birlikte Batı ve komünizm karşıtlığ1 konularında bu karşıtllğı benimseyen siyasi ve sosyal hareketlere yakın görünmektedir. Yazarın anılarına da yansıyan farklı siyasi tutumları ve bunların neticesinde partilerle kurduğu ilişkiler oldukça karmaşıktır. Aslında ilişkili olduğu her partiye, kendi fikriyatı ve aksiyonunun destekleyicisi kuruluşlar olarak bakmıştır. DP'yle kurduğu ilişkiden bu yana aynı yaklaşımın olduğu söylenebilir. Tabi bu durum iddialı bir mütefekkir olarak Necip Fazıl'ı politikanın ve politikacıların içinde zaman zaman sorunlu tavırlar almaya zorlar.

Yazar; mahkemeler, tutuklamalar, dergi ve gazete kapatmaları arasında Türkiye'yi dolaşmış ve yıllar içinde çok sayıda konferans vermiştir. Yazarak ve konuşarak etkilediği milyonlarca insan, ylllar içinde artmış, büyümüş, sonra yeni nesiller onu dinlemeye ve okumaya başlamıştır. Milliyetçimukaddesatçı hassasiyetlerin yükselmesinde, bu hassasiyete sahip insanların güçlenmesinde ve bilinçlerinin artmasında Necip Fazıl bir okul olmuştur. Anılarında bu çabalarının neticelerinden bahseder. Büyük Doğu davası dediği idealine Anadolu'dan en büyük ilginin Kayseri'den geldiğini söyler. Bu şehirden sonra Erzurum, Van, Elazığ, Konya ve bazı Ege Bölgesi kasabalarını saysa da 
en büyük teveccüh Kayseri'dendir (Kısakürek, 2010: 330). Yazarın çabalarının tezahürünü gördüğü kurum ise Milli Türk Talebe Birliğidir (MTTB).

Her ân şanlı süvarilerinin nal seslerini beklediğimiz bu gençliğin fideliği, bugün, Bâblâli'de, Cağaloğlu'nda, Halk Partisinin 6 okundan kinâye 6 sütun üzerindeki binada, çatısında “Türk’ün ruh kökü” yazılı bir sancak dalgalanan Millî Türk Talebe Birliğidir. Büyük Doğu gençliğinin maya tutmaya, billûrlaşmaya ve ilk merkeziyetini MT'TB'de kurmaya başlaması, ihtilâlden, 1965 'ten ve telgraf şebekesi halinde gezilip verilen Anadolu konferanslarından sonradır. (Kisakürek, 2010: 328-329)

Necip Fazıl Kısakürek, milliyetçi mukaddesatçı gençliği çağın içinden bir mütefekkir olarak etkilemiş; onların, Türkiye'nin sosyal ve siyasal hayatında söz sahibi olacak insanlar haline gelmesinde büyük rol oynamıştır. Milliyetçi-mukaddesatçı fikirlerin takipçileri genel olarak ona ayrı bir önem vermişlerdir. Yazar bu fikirlerin mensupları gözünde Türkiye'nin milli ve manevi değerleri için büyük mücadele veren bir mütefekkir ve şairdir. $\mathrm{Bu}$ fikirlerin temsilcisi durumundaki kuruluşlarla ilişkisi vardır, MTTB ile olan yakınlığı gibi. Ancak zaman zaman kimi çevrelerle arasının açıldığı, farklı kuruluşlara da teveccüh gösterdiği olmuştur. Bunlar Necip Fazıl Kısakürek’in siyasi ve sosyal aksiyonu içinde, bulunduğu şartları yorumlayarak aldığı farklı konumlardır.

N. Fazıl, MTTB'yi “karanlıktan alacaya, alacadan süt beyaza inkılap eden bir teşkilat" olarak görürken, MTTB de N. Fazll’ı “öz babamızdan daha önemli” biri olarak görüyordu. N. Fazıl'ın hayatında yaşadığı gelgitler hariç tutulursa uzun bir dönem bu ilişki devam etmiştir. N. Fazıl bir dönem Erbakan’a kızıp MHP ve Ülkü Ocaklarını desteklemiş, bir dönem de MTTB’ye kızarak beklediği gençliği Akıncı gençlik olarak ilan etmiştir. Her şeye rağmen N. Fazıl, MTTB'nin hemen hemen her faaliyetinde en ön sıralarda yer almıştır. (Yorgancılar, 2006: 140)

Necip Fazıl Kısakürek'in hatıratında sosyal ve siyasi konular dendiğinde dikkat çeken hususlardan biri de şairin çokça yargılanması ve hapse girip çıkmasıdır. Birçok edebiyatçı ve mütefekkir gibi o da yıllarca hapsi istenen kişiler arasındadır. Bazen tutuklu bulunduğu hâlde başka bir davadan dolayı ayrı bir dava açıldığı olmuştur.

Necip Fazıl aleyhine açılan yüze yakın davanın hepsi fikir suçuyla ilgilidir. O Türk tarihi ve toplumu ile ilgili hakikatleri dile getirdiği için hakikati korku ve şiddet kullanarak değiştirebileceğini zannedenler tarafindan sanık sandalyesine oturtuldu. Aslında sanık sandalyesine oturan Necip Fazıl değil, onun şahsında milletin ruhuydu. Bu ruhu temsil etmek ona güç verdi, cesaret verdi, canlllık verdi. (Karatepe, 1994: 164)

Necip Fazıl'ın hayatı, XX. yüzyıl Türkiye'sinde özgür bir düşünce ve ifade ortamının olmadığının kanıtlarından biridir. Burada şunu eklemeliyiz ki sadece Necip Fazıl değil, farklı görüşlere mensup çok sayıda edebiyatçı hapis cezaları almış, yıllarca mahkûmiyet yaşamıştır.

\section{Sonuç}

Hatırat türündeki kitapların bir kısmı yazarının hayat hikâyesinden fazlasını gösterir. Edebiyatçılar arasında toplum davalarını önemsemiş isimlerin hatıratı böyle eserlerdir. Bir şair ve düşünce adamı olarak Necip Fazıl Kısakürek, yaşadığı çağın sosyal ve siyasi konularına kayıtsız kalmaz. Türkiye'deki pek çok tarihi olayın tanığı olması, onun hatırat kitaplarını sosyal ve siyasi tarih bakımından önemli kılmıştır. Naklettiği olaylar ve konular arasında -özel hayatı dışında- edebiyat ve basın hayatıyla döneminin güncel politikası dikkat çeker. Bunları anlatırken büyük ölçüde kendi görüşleri ve yaşadıkları içinde kalmıştır. Dolayısıyla yazarın hatırat kitapları, hatırat bir tarih kitabı olmadığı için, anlattığı olayların geçtiği dönemler içinde yaşanan olayların ancak bir kısmını yansıtır. Yazarın bahsettikleri yanında bahsetmedikleri arasında da Cumhuriyet Dönemi’nin mühim olayları vardır. 
An1 kitaplarındaki sosyal ve siyasi konuların zaman dilimi 1910'lu y1llardan 1970’lere kadardır. Cumhuriyet öncesine dair nadir olan konular, yıllar ilerledikçe genişlemiştir. Özellikle dinî bilincinin artmaya başladığı yıllardan itibaren cemiyet meseleleri ve Türkiye'nin durumu üzerinde daha çok düşünmüş, sorumluluk duygusuyla hareket etmiştir. Dolayısıyla yazarın anılarında 1930’ların ortasından itibaren çok sayıda sosyal ve siyasi konu karşımıza çıkmıştır.

Necip Fazıl'ın anlattıkları içinde siyasete-partilere dair konular ve meseleler çokça görülmektedir. Bunun nedeni şairin hemen hemen tüm iktidarlarla arasında bir irtibat ve aynı zamanda ciddi problemler olmasıdır. Bütün iktidarlarla sorunlar yaşadığı görülmüştür. Tek parti döneminde muhalif kimliği baskındır. Demokrat Parti döneminde bir yandan örtülü ödenekten yardım alıp Başbakan Menderes'le irtibat halindeyken öte yandan birçok kez yargılanmış, hapis cezaları almıştır. 27 Mayıs dönemini ve anılarında yer verdiği sonraki iktidarları da tasvip etmemiştir. Milliyetçi-mukaddesatçı söylemin içinde kalan partilere kısmen destek verse de Necip Fazıl iktidarlarla uyuşamamıştır.

Necip Fazıl Kısakürek, sosyal ve siyasi konular karşısında aldığı tavırlarla Türkiye'deki muhafazakâr düşünce içindeki kesimleri etkilemeyi başarır. Düşünceleri yayılmış ve gerek siyasi hareketlerde gerekse toplumsal bilinç ve hafızada yer etmiştir. Savundukları ve karşı çıktıkları, okurları nezdinde bir süre sonra sembolleșen olumlu ve olumsuz unsurlar haline gelmiştir. Yazar, savundukları ve karşı çıktıklarıyla Türkiye'de muhafazakâr retoriğin oluşmasına ciddi bir katkı yapmıştır. Hatıratında bu retoriğin unsurlarından Batı karşıtlı̆̆ı, zararlı sayılan basın organlarıyla mücadele, komünizm karşıtlı̆̆1, CHP’ye karşı sağ partilerin desteklenmesi, milli ve manevi değerlerin sahiplenilmesi, canlı ve etkin bir gençlik oluşturma hedefi işlenen başlıca konulardır.

Yazarın hatırat kitapları, tanığı olduğu yıllara kendi penceresinden bakan, sübjektif hükümlere sıkça rastlanan, birçok tanınmış isim hakkında genellikle olumsuz değerlendirmelerin yapıldığ1 eserlerdir. Sübjektif hükümlerin fazla oluşu, eserlerinin güçlü tarafı olarak düşünülmelidir. Sosyal ve siyasi konulardaki tanıklıklarını güçlü yorumlar ve hükümlerle okurlara sunması, kitaplarında kendinden emin bir şahsiyet olarak görünmesini sağlar. Tabi bu durum zaman zaman aşırı yorumlarla hakkında konuştuğu olay ve kişileri olduğundan farklı değerlendirmesine de sebep olmuştur, itham edici bir tavırla değerlendirmeler yapmıştır. Necip Fazıl, mücadele ettiği siyasi ve kültürel iktidar merkezlerine karşı kendi fikriyatından ve davasından emin olan tavrıyla okurları nezdinde öncü bir kişilik ve hatta bir kahraman figür haline gelmiştir. Anılarında naklettiği olaylar ve tutumları, bu öncü ve kahraman figürü destekleyici bir içerik sunar. Onun nesli, geniş muhafazakâr kitlelerin sözcülügünü üstlenecek imkânlardan yoksunken veya buna yeteri kadar cesaret edemezken Necip Fazıl zor zamanlarda ve şartlar altında bu sorumluluğu almıştır.

\section{Kaynakça}

ACAR, Ayla (2012/II). "Basında 'Tan Olay1'- 4 Aralık 1945”, İstanbul Üniversitesi İletişim Fakültesi Dergisi, (43): 1-22.

AK, Suat (2016). Necip Fąll ve Büyü̈k Doğu-Sosyal-Siyasi Mücadele Taribi-, İstanbul: Büyüyen Ay Yayınları.

AKBULUT, Dursun Ali (2006). Saltanattan Ulusal Egemenliğe, İstanbul: Temel Yayınlar1.

ARABACI, Caner (2014). "Necip Fazıl'ın Bâbıâli Eseri ve Basına Eleştirel Yaklaşımı”, Uluslararası Necip Faz̨l Kısakürek Sempozyumu Bildiriler Kitabı, ed. Alim Gür, Ali Temizel ve Harun Yıldız, ss. 113-128, Konya: Konya Büyükşehir Belediyesi Kültür Yayınları.

Büyük Doğu Gazetesi (09.07.1952). (İmzasız haber).

ÇAĞAN, Kenan (2013). “Necip Fazıl ve Siyaset”, Öæü Yüəünden Okumak: Büyük Doğu Kapaklarmm Dili, haz. M. Fatih And1 ve Bahtiyar Aslan, ss. 83-100, İstanbul: Küçükçekmece Belediyesi Kültür Yayınları. 
ÇIKLA, Selçuk (2007). "Türk Edebiyatında Kanon ve İnk1lâp Kanonu”, Mubafazakâr Düsünce, (13-14): 47-68.

DURAN, Burhanettin (2015). “Necip Fazıl Kısakürek’te Tek Parti ve Kemalizm Eleştirisi”, Necip Fą̨l Kitabı-Semposynum Tebliğleri, ed. Asım Öz, İsmail Kara ve Aykut Ertuğrul, ss. 523-529, İstanbul: Zeytinburnu Belediyesi Kültür Yayınları.

KAHRAMAN, Alim (2010). “ 'Büyük Hayat'1 Gören Aç”, Necip Fą̨l Kısakürek, ed. Mehmet Nuri Şahin ve Mehmet Çetin, ss. 297-303, Ankara: Kültür ve Turizm Bakanlığı Yayınları.

KARACA, Alaattin (14.03.2016). "İstiklâl Marşı Etrafındaki Tartışmalar”, Karar Gazetesi, Erişim Tarihi: 25.12.2020, (https://www.karar.com/yazarlar/alaattin-karaca/istiklal-marsietrafindaki-tartismalar-242).

KARAOSMANOĞLU, Yakup Kadri (2018). Politikada 45 Yl, İstanbul: İletişim Yayınlanı.

KARATEPE, Şükrü (1994). "Necip Fazıl Davaları”, Bütün Yönleriyle Necip Faz̨l, ss. 160165, Ankara: Türkiye Yazarlar Birliği Yayınları.

KARPAT, H. Kemal (2019). Kısa Türkizye Taribi 1800-2012, İstanbul: Timaş Yayınları.

KAYA, Halit (2008). Refet Bele'nin Askerî ve Siyasi Hayatı (1881-1963), (Yüksek Lisans Tezi), Ankara Üniversitesi Türk İnk1lâp Tarihi Enstitüsü, Ankara.

KISAKÜREK, Necip Fazıl (2010). Bâbıâli, İstanbul: Büyük Doğu Yayınları. Yayınevi.

KISAKÜREK, Necip Fazil (1970). Benim Gözümde Adnan Menderes, İstanbul: Ötüken

KISAKÜREK, Necip Fazıl (2018). Cinnet Mustatili, İstanbul: Büyük Doğu Yayınları.

KISAKÜREK, Necip Faz1l (1973). Cumburiyetin 50. Yllnda Türkiye'nin Manzarası, İstanbul: Büyük Doğu Yayınları.

KISAKÜREK, Necip Fazıl (1992). Hücûm ve Polemik, İstanbul: Büyük Doğu Yayınları.

KISAKÜREK, Necip Fazıl (1998). O ve Ben, İstanbul: Büyük Doğu Yayınları.

KOÇAK, Mesut (2020). Necip Fąֶl Kısakürek, Köln: Plural Publications GmbH.

LAÇ, Abdurrahman Şeref (02.08.1952). “Âdil ve Tarafsız Savcı! Vazife Başına!”, Büyük Doğu Gazetesi. Gazetesi.

LAÇ, Abdurrahman Şeref (20.06.1952). "Beynelmilel Münafik Yalman'a”, Büyük Doğu

ÖZDEMIROĞLU, N. Turgut (12.08.1952). "Sonu Gelmeyen Lânet” (Okuyucu mektupları sütununun başlı̆̆ı), Büyük Doğu Gazetesi.

SERTEL, M. Zekeriya (1968). Hatırladıklarm, İstanbul: Yaylacık Matbaası.

TÜRINAY, Necmettin (1994). "Necip Fazıl ve Politika”, Bütün Yönleriyle Necip Fa乞ıl, ss. 139-150, Ankara: Türkiye Yazarlar Birliği Yayınları.

Ulus Gazetesi (10.11.1937). Erişim Tarihi: 25.12.2020, (http://nek.istanbul.edu.tr:4444/ekos/GAZETE/ulus/ulus_1937/ulus_1937_sontesrin_/ulus_1 937_sontesrin_10_.pdf).

Ulus Gazetesi (11.01.1938). "Marş Müsabakamı", Erişim Tarihi: 25.12.2020, (http://nek.istanbul.edu.tr:4444/ekos/GAZETE/ulus/ulus_1938/ulus_1938_sonkanun_/ulus_ 1938_sonkanun_11_.pdf).

Ulus Gazetesi (14.11.1937). "Marş Müsabakamı", Erişim Tarihi: 25.12.2020, (http://nek.istanbul.edu.tr:4444/ekos/GAZETE/ulus/ulus_1937/ulus_1937_sontesrin_/ulus_1 937_sontesrin_14_.pdf). 
ÜSTÜN, Nazan (2011). Büyük Doğu Mecmuası'nın Siyasal Analizi, (Yayımlanmamış Yüksek Lisans Tezi), İstanbul Üniversitesi Sosyal Bilimler Enstitüsü, İstanbul.

ÜZMEZ, Hüseyin (1996). Malatya Suikast, İstanbul: Timaş Yayınları.

Vatan Gazetesi (03.12.1952). "Sahte Mürşit Suikastı Nasıl Tahrik Etmişti?”, Erişim Tarihi: 11.01.2021,(http://nek.istanbul.edu.tr:4444/ekos/GAZETE/vatan/vatan_1952/vatan_1952_ara lik_/vatan_1952_aralik_3_.pdf).

Vatan Gazetesi (04.12.1952). "Necip Fâzıl'ın Tevkîfi Lâzımdır”, Erişim Tarihi: 11.01.2021, (http://nek.istanbul.edu.tr:4444/ekos/GAZETE/vatan/vatan_1952/vatan_1952_aralik_/vatan_ 1952_aralik_4_.pdf).

Vatan Gazetesi (25.11.1952). “Malatya Hadisesi'nin Tahkikatı İstanbul'a da İntikal Etti”, Erişim Tarihi:

11.01.2021, (http://nek.istanbul.edu.tr:4444/ekos/GAZETE/vatan/vatan_1952/vatan_1952_kasim_/vatan _1952_kasim_25_\%20(2).pdf).

YAVUZ, Uğur Günay (2016). “II. Dünya Savaşı'nın Cumburiyet ve Tan Gazetelerinde Temsili”, Karadeniz Teknik Üniversitesi İletisim Araştormalar Dergisi, 3(11): 2-31.

YORGANCILAR, Serkan (2006). 1965 Sonrası İslamcı Bir Öğrenci Hareketi Olarak Milli Türk Talebe Birliği, (Yayımlanmamış Yüksek Lisans Tezi), Dokuz Eylül Üniversitesi Sosyal Bilimler Enstitüsü, İzmir.

YÜREKLİ, Mustafa (2014). "Necip Fazıl Kisakürek’in Siyasete Etkisi”, Uluslararası Necip Fazıl Kısakürek Sempozyumu Bildiriler Kitabı, ed. Âlim Gür, Ali Temizel ve Harun Yıldız, ss. 675-689, Konya: Konya Büyükşehir Belediyesi Kültür Yayınları.

ZÜRCHER, Erkk Jan (2018). Modernleşen Türkiye'nin Taribi, çev. Yasemin Saner, İstanbul: İletişim Yayınları. 